\title{
Hydrothermal synthesis of anisotropic alkali and alkaline earth vanadates
}

\section{Conference Paper}

\section{Author(s):}

Michailovski, Alexej; Wörle, Michael; Sheptyakov, Denis; Patzke, Greta R.

Publication date:

2007

Permanent link:

https://doi.org/10.3929/ethz-b-000004967

Rights / license:

In Copyright - Non-Commercial Use Permitted

Originally published in:

Journal of Materials Research 22(1), https://doi.org/10.1557/JMR.2007.0002 


\title{
OUTSTANDING MEETING PAPERS
}

Papers in this section are based on submissions to the MRS Symposium Proceedings that were selected by Symposium Organizers as the outstanding paper. Upon selection, authors are invited to submit their research results to Journal of Materials Research. These papers are subject to the same peer review and editorial standards as all other JMR papers. This is another way by which the Materials Research Society recognizes high quality papers presented at its meetings.

\section{Hydrothermal synthesis of anisotropic alkali and alkaline earth vanadates}

\author{
Alexej Michailovski and Michael Wörle \\ Laboratory of Inorganic Chemistry, ETH Zurich, CH-8093 Zurich, Switzerland \\ Denis Sheptyakov \\ Laboratory for Neutron Scattering, ETH Zurich \& PSI Villigen, CH-5232 Villigen PSI, Switzerland \\ Greta R. Patzke ${ }^{\text {a) }}$ \\ Laboratory of Inorganic Chemistry, ETH Zurich, CH-8093 Zurich, Switzerland
}

(Received 18 April 2006; accepted 12 July 2006)

\begin{abstract}
In the course of a systematic field study, anisotropic alkali and alkaline earth vanadates have been accessed through a straightforward, one-step hydrothermal process. They are formed quantitatively from $\mathrm{V}_{2} \mathrm{O}_{5}$ and alkali- or alkaline earth halide solutions after a few days of autoclave treatment in the temperature range between 100 and $220{ }^{\circ} \mathrm{C}$. The presence of ionic additives leads to an interplay between the formation of isotropic crystalline phases and the production of fibrous oxide materials, such as a novel magnesium vanadate. The influence of the hydrothermal parameters and of the alkali/alkaline earth halides on the emerging phases and morphologies has been investigated in the course of a systematic study. The results are compared with other vanadate- and transition metal oxide-based hydrothermal systems, and the emerging trends are discussed with respect to the development of predictive synthetic concepts for nanostructured vanadium oxides.
\end{abstract}

\section{INTRODUCTION}

Anisotropic oxidic nanoparticles are important tools for a future nanotechnology, ${ }^{1}$ and hydrothermal methods ${ }^{2}$ provide a versatile and efficient synthetic approach for their large-scale synthesis. Their preparative convenience has recently been demonstrated for the formation of molybdenum oxide fibers, ${ }^{3,4}$ and the present study is focused on a hydrothermal pathway to anisotropic vanadates. The hydrothermal preparation and the sol-gel chemistry of vanadium oxides has been in the focus of research interest over the past decades. In combination with the exceptionally rich structural chemistry of vanadates, these efforts have brought forward a multitude of promising novel materials. Table I provides a summary of review articles covering this extensive field of vanadate-based materials chemistry. ${ }^{5-11}$ The structural chemistry of vanadium oxides benefits from the variety of vanadium oxidation states and the manifold coordination environments that vary from tetrahedra over trigonal

\footnotetext{
a) Address all correspondence to this author. e-mail: patzke@inorg.chem.ethz.ch

This paper was selected as the outstanding meeting paper for the 2005 MRS Spring Meeting Symposium Y Proceedings, Vol. 878E. DOI: $10.1557 / J M R .2007 .0002$
}

and square pyramids to regular and distorted octahedra. ${ }^{9}$ These polyhedra can be combined into cluster compounds, chain and layer structures, and threedimensional frameworks. ${ }^{12}$ They exhibit a wide spectrum of important applications, especially in cataly$\operatorname{sis}^{13,14}$ and in electrochemistry. ${ }^{15}$ The materials chemistry of vanadates could be substantially enhanced by shape-controlling syntheses on the nanoscale, ${ }^{16,17}$ such as the formation of vanadium oxide nanotubes ${ }^{18,19}$ or the self-assembly of $\mathrm{VO}_{2}$ nanorods. ${ }^{20}$

The scope of the present study is a hydrothermal field screening of the $\mathrm{MX}_{\mathrm{n}} / \mathrm{V}_{2} \mathrm{O}_{5}(\mathrm{n}=1,2 ; \mathrm{M}=$ alkali/ alkaline earth cation; $\mathrm{X}=\mathrm{OH}, \mathrm{F}-\mathrm{I}$ ) systems with respect to the formation of anisotropic vanadates with diameters on the nano- and submicrometer scale. Although numerous studies have been conducted on the hydrothermal preparation of specific alkali and alkaline earth vanadates (cf. the summary in Tables II and III), ${ }^{21-44}$ their morphochemistry is still far from explored, let alone the hydrothermal mechanisms leading to fiber formation. Thus, we present the first comparative morphological study vanadates formed by the hydrothermal interaction of $\mathrm{V}_{2} \mathrm{O}_{5}$ with alkali/alkaline earth hydroxides and halides. These systems were selected for the following reasons. 
TABLE I. Selection of review articles covering the solution-based synthesis and materials chemistry of vanadates.

\begin{tabular}{ccc}
\hline \hline \multicolumn{1}{c}{ Review topic } & Vanadate systems & Reference \\
\hline $\begin{array}{c}\text { Hydrothermal synthesis of } \\
\text { vanadium oxides }\end{array}$ & $\begin{array}{c}\text { Lithium vanadates, } \\
\text { vanadium oxides } \\
\text { containing organic } \\
\text { species }\end{array}$ & 5 \\
$\begin{array}{c}\text { Sol-gel chemistry of } \\
\text { vanadium pentoxide: } \\
\text { electrochemical and } \\
\text { catalytic properties } \\
\text { intercalation } \\
\text { oxides: synthesis and } \\
\text { intercalation properties }\end{array}$ & $\begin{array}{c}\text { compounds } \\
\text { Intercalation compounds, } \\
\text { Vanadium oxides for lithium } \\
\text { batteries }\end{array}$ & $\begin{array}{c}\text { nanotube arrays } \\
\text { Vanadium phosphates, } \\
\text { lithium vanadates etc. }\end{array}$ \\
$\begin{array}{c}\text { Structural chemistry } \\
\text { Vanadium oxides with } \\
\text { open frameworks }\end{array}$ & 7 \\
$\begin{array}{c}\text { Vanadium oxide } \\
\text { architectures: manipulation } \\
\text { of the solid state structure } \\
\text { Simulation of crystal } \\
\text { structures and surfaces }\end{array}$ & $\begin{array}{c}\text { incorporating organic } \\
\text { components }\end{array}$ & 9 \\
\hline \hline
\end{tabular}

The idea of tuning the aspect ratio of nanoparticles by the use of capping additives in hydrothermal synthesis is intriguing and has been demonstrated for various oxidic materials such as $\mathrm{ZnO} .{ }^{45}$ However, it may still take considerable optimization effort to single out additive substances for vanadate systems because corresponding studies on the additive-assisted hydrothermal growth of anisotropic molybdenum oxides have shown that the majority of the investigated substances either did not exert a significant morphology control under the given conditions or that they were incorporated to form new molybdates. ${ }^{46}$ Selected combinations of ionic additives may provide an alternative way of generating new morphologies: when molybdenum(VI)-precursors were reacted in mixed alkali halide solutions, a new type of fibrous cesium potassium molybdates emerged. ${ }^{47}$

In the course of catalytical studies, the crystal morphology of $\mathrm{V}_{2} \mathrm{O}_{5}$ has been simulated, and the results have been applied to develop a model for $\mathrm{V}_{2} \mathrm{O}_{5} / \mathrm{TiO}_{2}$ thin films. ${ }^{11}$ Nevertheless, little is known about the interaction of vanadate surfaces with alkali/alkaline earth cations. In the following paragraphs, the main trends emerging from our extensive hydrothermal parameter study (encompassing over 200 experiments) are presented. This systematic investigation has been devised to single out the most promising systems with respect to anisotropic vanadate growth as a starting point for forthcoming detailed explorations of their formation processes and applications: firstly, the $\mathrm{MX} / \mathrm{V}_{2} \mathrm{O}_{5}$-systems $(\mathrm{M}=\mathrm{Li}$, $\mathrm{Na}$ ) are discussed as representative examples that outline the preparative assets and drawbacks of the hydrothermal approach. Furthermore, key results concerning the use of alkaline earth-based additives are presented.

\section{EXPERIMENTAL}

If not mentioned otherwise, a standard hydrothermal experiment was performed as follows: $360 \mathrm{mg} \mathrm{V}_{2} \mathrm{O}_{5}$ (Fluka, 99.5\%) and the appropriate amount of additive (alkali/alkaline earth halide or hydroxide; Fluka, Aldrich, min. $>99.5 \%$ ) necessary to adjust the initial M:V-ratio were added together with $1.5 \mathrm{~mL}$ of distilled water to a Teflon-lined stainless steel autoclave with the capacity of $23 \mathrm{~mL}$. The autoclave was then sealed, heated at $180{ }^{\circ} \mathrm{C}$ for 6 days and subsequently cooled to room temperature. The precipitate was collected after filtration, washed with distilled water, ethanol, and ether and dried in air. Based on this standard procedure, a total of over 200 parameter screening experiments was performed with emphasis on the influence of the M:V-ratio on the structure and morphology of the products. X-ray powder analysis was conducted on a STOE STADI-P2 diffractometer (STOE \& Cie., Darmstadt, Germany) in transmission mode (flat sample holders, Ge-monochromated $\mathrm{CuK}_{\alpha 1}$ radiation) equipped with a position sensitive detector (resolution $\sim 0.01^{\circ}$ in $2 \theta$ ). The synchrotron $x$-ray powder diffraction data for $\mathrm{Mg}_{7-\mathrm{x}}\left(\mathrm{VO}_{4}\right)_{4}(\mathrm{OH})_{3}$ (cf. Fig. 9) were collected at the BM16 beamline of the European Synchrotron Radiation Facility (ESRF) with the wavelength of $0.5018 \AA$. For scanning electron microscopy (SEM), performed on a LEO 1530 (FEG) microscope with $1 \mathrm{keV}$ electrons, samples were dispersed in ethanol and subsequently deposited on a silicon wafer. Alkali metal:vanadium-ratios were determined by means of inductively coupled plasma (ICP) analysis (ELAN 6100 DRC, Perkin Elmer/ Sciex) in the standard mode. For the determination of alkali contents, $20-40 \mathrm{mg}$ of the fibrous vanadates were dissolved in $65 \%$ nitric acid and adjusted to an overall acid concentration of $2 \%$. The obtained solution was diluted (1:40) with double distilled water and readjusted to $2 \%$ nitric acid for analysis of the vanadium content.

\section{RESULTS: HYDROTHERMAL SYNTHESIS OF ANISOTROPIC ALKALI VANADATES}

\section{A. Hydrothermal screening experiments in the $\mathrm{MX} / \mathrm{V}_{2} \mathrm{O}_{5}$ systems ( $\mathrm{M}=\mathrm{Li}-\mathrm{Cs} ; \mathrm{X}=\mathrm{OH}, \mathrm{F}-\mathrm{I}$ )}

The choice of the alkali cation exerts a key influence on the morphology of the products emerging from the hydrothermal formation of anisotropic alkali vanadates. All results are summarized in Tables IV to VI. The smaller alkali cations, $\mathrm{Li}^{+}$and $\mathrm{Na}^{+}$, display the highest tendency towards fiber formation, whereas the average degree of anisotropy in the products declines with increasing size of the alkali cation. Moreover, the role of the anion must be taken into account: the "hardest" anions, $\mathrm{OH}^{-}$and $\mathrm{F}^{-}$, favor the growth of fibrous products, whereas the "softer" halides $\left(\mathrm{Cl}^{-}-\mathrm{I}^{-}\right)$tend to reduce the aspect ratio of the emerging alkali vanadate particles. However, an excess of alkali hydroxide and fluoride 
TABLE II. Literature survey of hydrothermal syntheses of alkali vanadates.

\begin{tabular}{|c|c|c|c|c|}
\hline Alkali vanadate & Hydrothermal parameters & Morphology & Investigated properties & Reference \\
\hline$\beta \mathrm{III}-\mathrm{Li}_{3} \mathrm{VO}_{4}$ & $\begin{array}{l}\mathrm{V} \text { anode, } \mathrm{LiOH}(\mathrm{aq}) \\
\text { hydrothermal-electrochemical }\end{array}$ & Thin films & $\begin{array}{l}\text { Electrochemical } \\
\text { performance }\end{array}$ & 21 \\
\hline $\mathrm{Li}_{0.6} \mathrm{~V}_{2-\delta} \mathrm{O}_{4-\delta} \cdot \mathrm{H}_{2} \mathrm{O}$ & $\begin{array}{l}\mathrm{V}_{2} \mathrm{O}_{5} / \mathrm{tmaOH} / \mathrm{LiOH} / \\
\mathrm{HNO}_{3} ; 2 \mathrm{~d}, 200^{\circ} \mathrm{C}\end{array}$ & Lamellar crystals & $\begin{array}{l}\text { Electrochemical } \\
\text { performance }\end{array}$ & 22 \\
\hline $\mathrm{Li}_{\mathrm{x}} \mathrm{V}_{2-\delta} \mathrm{O}_{4-\delta} \cdot \mathrm{H}_{2} \mathrm{O}$ & $\begin{array}{l}\mathrm{V}_{2} \mathrm{O}_{5} / \mathrm{LiOH} \cdot \mathrm{H}_{2} \mathrm{O} / \\
\mathrm{N}_{2} \mathrm{H}_{4} \cdot \mathrm{H}_{2} \mathrm{O} ; 1 \text { day, } 160^{\circ} \mathrm{C}\end{array}$ & Nanorods & Hydrothermal study & 23 \\
\hline $\mathrm{LiV}_{3} \mathrm{O}_{8}$ & $\begin{array}{l}\mathrm{V}_{2} \mathrm{O}_{5} / \mathrm{LiOH} / \mathrm{NH}_{4} \mathrm{OH} \\
\text { followed by annealing }\end{array}$ & Nanorods & $\begin{array}{l}\text { Morphology and } \\
\text { electrochemistry }\end{array}$ & 24 \\
\hline $\begin{array}{l}\mathrm{Li}_{\mathrm{x}} \mathrm{V}_{\mathrm{y}} \mathrm{O}_{2} \\
\quad(\mathrm{x}=0.86, \mathrm{y}=0.8)\end{array}$ & $\begin{array}{r}\mathrm{V}_{2} \mathrm{O}_{3} / \mathrm{LiOH} \cdot \mathrm{H}_{2} \mathrm{O} \\
4 \text { days, } 180^{\circ} \mathrm{C}\end{array}$ & Powders & $\begin{array}{l}\text { Electrochemical } \\
\text { properties }\end{array}$ & 25 \\
\hline $\begin{array}{l}\mathrm{M}_{0.3} \mathrm{~V}_{2} \mathrm{O}_{5} \cdot \mathrm{nH}_{2} \mathrm{O} \\
\quad\left(\mathrm{M}=\mathrm{Na}-\mathrm{Cs}, \mathrm{NH}_{4}\right)\end{array}$ & $\begin{array}{c}\mathrm{VOSO}_{4} / \mathrm{M}_{2} \mathrm{SO}_{4} \\
200-220^{\circ} \mathrm{C}\end{array}$ & $\begin{array}{l}\text { Rod-shaped } \\
\text { single crystals }\end{array}$ & Structure analysis & 26 \\
\hline$\left(\mathrm{NH}_{4}\right)_{0.5} \mathrm{~V}_{2} \mathrm{O}_{5}$ & $\begin{array}{l}\mathrm{NH}_{4} \mathrm{VO}_{3} \\
\quad 2 \text { days, } 170{ }^{\circ} \mathrm{C}\end{array}$ & $\begin{array}{l}\text { Self-assembled } \\
\text { nanowires }\end{array}$ & $\begin{array}{l}\text { Morphology, } \\
\text { semiconductivity }\end{array}$ & 27 \\
\hline $\begin{array}{l}\mathrm{MV}_{3} \mathrm{O}_{8} \\
\quad(\mathrm{M}=\mathrm{K}-\mathrm{Cs})\end{array}$ & $\begin{array}{l}\mathrm{V}_{2} \mathrm{O}_{5} / \mathrm{MNO}_{3} \\
48 \mathrm{~h}, 250^{\circ} \mathrm{C}\end{array}$ & Single crystals & Structure analysis & 28 \\
\hline $\begin{array}{c}\mathrm{M}_{\mathrm{x}} \mathrm{V}_{3} \mathrm{O}_{8}(\mathrm{VO})_{\mathrm{y}} \cdot \mathrm{nH}_{2} \mathrm{O} \\
(\mathrm{M}=\mathrm{K}, \mathrm{Rb}, \mathrm{Ba})\end{array}$ & $\begin{array}{l}\mathrm{VOSO}_{4} / \mathrm{M}_{2} \mathrm{SO}_{4} \\
24-28 \mathrm{~h}, 200-250{ }^{\circ} \mathrm{C}\end{array}$ & $\begin{array}{l}\text { Flat, fibrous } \\
\text { crystals }\end{array}$ & Structural studies & 29 \\
\hline $\begin{array}{l}\mathrm{M}_{2} \mathrm{~V}_{6} \mathrm{O}_{16} \cdot \mathrm{nH}_{2} \mathrm{O} \\
(\mathrm{M}=\mathrm{K}, \mathrm{Rb}, \mathrm{Ba})\end{array}$ & $\begin{array}{l}\mathrm{V}_{2} \mathrm{O}_{5} / \mathrm{M}_{2} \mathrm{SO}_{4} \\
48 \mathrm{~h}, 250^{\circ} \mathrm{C}\end{array}$ & Single crystals & Structure analysis & 29 \\
\hline $\mathrm{K}_{0.5} \mathrm{~V}_{2} \mathrm{O}_{5}$ & $\begin{array}{l}\mathrm{VO}(\mathrm{OH})_{2} / \mathrm{KCl} \\
24-48 \mathrm{~h}, 150-280^{\circ} \mathrm{C}\end{array}$ & $\begin{array}{l}\text { Single crystals, thin } \\
\text { platelets }\end{array}$ & $\begin{array}{l}\text { Structure } \\
\quad \text { determination }\end{array}$ & 30 \\
\hline $\mathrm{K}_{2} \mathrm{~V}_{3} \mathrm{O}_{8}$ & $\begin{array}{c}\mathrm{V}_{2} \mathrm{O}_{5} / \mathrm{KOH} / \mathrm{EtOH} \\
48 \mathrm{~h}, 200^{\circ} \mathrm{C}\end{array}$ & Nanorods & $\begin{array}{l}\text { Solvothermal study, } \\
\text { morphology }\end{array}$ & 31 \\
\hline $\mathrm{K}_{2} \mathrm{~V}_{3} \mathrm{O}_{8}$ & $\begin{array}{l}\mathrm{KVO}_{3} / \mathrm{KOH} / \text { adipic acid } \\
48 \mathrm{~h}, 180^{\circ} \mathrm{C}\end{array}$ & $\begin{array}{l}\text { Micro-patterned } \\
\text { sheets }\end{array}$ & Hydrothermal etching & 32 \\
\hline $\mathrm{Rb}_{0.5} \mathrm{~V}_{2} \mathrm{O}_{5}$ & $\begin{array}{l}\mathrm{VO}(\mathrm{OH})_{2} / \mathrm{RbCl} \\
24-48 \mathrm{~h}, 250-280{ }^{\circ} \mathrm{C}\end{array}$ & $\begin{array}{l}\text { Single crystals, } \\
\text { thin platelets }\end{array}$ & $\begin{array}{l}\text { Redox properties, } \\
\text { structural chemistry }\end{array}$ & 33 \\
\hline $\mathrm{Cs}_{2} \mathrm{~V}_{4} \mathrm{O}_{11}$ & $\begin{array}{l}\mathrm{VO}(\mathrm{OH})_{2} / \mathrm{CsVO}_{3} \\
30 \mathrm{~h}, 280^{\circ} \mathrm{C}\end{array}$ & $\begin{array}{l}\text { Yellow prismatic } \\
\text { crystals }\end{array}$ & Structure determination & 34 \\
\hline
\end{tabular}

TABLE III. Literature survey of hydrothermal syntheses of alkaline earth vanadates.

\begin{tabular}{|c|c|c|c|c|}
\hline Alkaline earth vanadate & Hydrothermal parameters & Morphology & Investigated properties & Reference \\
\hline $\begin{array}{l}\text { Calcium vanadates } \\
\text { (e.g., smerwoodite) }\end{array}$ & $\begin{array}{l}\mathrm{V}_{2} \mathrm{O}_{5} / \mathrm{Ca}(\mathrm{OH})_{2} ; 20-350 \mathrm{~atm} \\
\quad 200-600^{\circ} \mathrm{C}\end{array}$ & mm-size fibers & Hydrothermal study & 35 \\
\hline $\mathrm{Ca}_{0.25} \mathrm{~V}_{2} \mathrm{O}_{5} \cdot \mathrm{H}_{2} \mathrm{O}$ & $\begin{array}{l}\mathrm{VO}_{2} / \mathrm{CaCl}_{2} \\
\quad 48 \mathrm{~h}, 280^{\circ} \mathrm{C}\end{array}$ & Single crystals & Structure analysis & 36 \\
\hline $\mathrm{SrV}_{4} \mathrm{O}_{9}$ & $\begin{array}{l}\mathrm{NaVO}_{3} / \mathrm{SrCl}_{2} / \mathrm{NMe}_{4} \mathrm{Cl} \\
\quad 48 \mathrm{~h}, 350{ }^{\circ} \mathrm{C}\end{array}$ & Light green crystals & Structure determination & 37 \\
\hline $\mathrm{BaV}_{2} \mathrm{O}_{6}$ & $\begin{array}{c}\mathrm{VO}(\mathrm{OH})_{2} / \mathrm{Ba}\left(\mathrm{NO}_{3}\right)_{2} \\
24-48 \mathrm{~h}, 280^{\circ} \mathrm{C}\end{array}$ & $\begin{array}{l}\text { Columnar single } \\
\text { crystals }\end{array}$ & Structure determination & 38 \\
\hline $\mathrm{BaV}_{3} \mathrm{O}_{8}$ & $\begin{array}{c}\mathrm{VO}(\mathrm{OH})_{2} / \mathrm{BaCl}_{2} \\
40 \mathrm{~h}, 270^{\circ} \mathrm{C}\end{array}$ & $\begin{array}{l}\text { Single crystals } \\
\text { (black rods) }\end{array}$ & Structure determination & 39 \\
\hline $\mathrm{Ba}_{0.4} \mathrm{~V}_{3} \mathrm{O}_{8}(\mathrm{VO})_{0.4} \cdot \mathrm{nH}_{2} \mathrm{O}$ & $\begin{array}{l}\mathrm{VOCl}_{2} / \mathrm{BaCl}_{2} \\
24 \mathrm{~h}, 240{ }^{\circ} \mathrm{C}\end{array}$ & $\begin{array}{l}\text { Thin, long } \\
\text { plates }\end{array}$ & Structure determination & 40 \\
\hline $\mathrm{BaV}_{6} \mathrm{O}_{16} \cdot \mathrm{nH}_{2} \mathrm{O}$ & $\begin{array}{l}\mathrm{VO}(\mathrm{OH})_{2} / \mathrm{BaCl}_{2} \\
24-48 \mathrm{~h}, 250-280^{\circ} \mathrm{C}\end{array}$ & $\begin{array}{l}\text { Needle-shaped single } \\
\text { crystals }\end{array}$ & Structure determination & 41 \\
\hline $\mathrm{BaV}_{7} \mathrm{O}_{16} \cdot \mathrm{nH}_{2} \mathrm{O}$ & $\begin{array}{l}\mathrm{V} \text {-anode/ } \mathrm{Ba}\left(\mathrm{NO}_{3}\right)_{2} \\
\quad \text { hydrothermal-electrochemical }\end{array}$ & Single crystals & Structure determination & 42 \\
\hline $\mathrm{Ba}_{1+\mathrm{x}} \mathrm{V}_{8} \mathrm{O}_{21}$ & $\begin{array}{l}\mathrm{VO}_{2} / \mathrm{Ba}\left(\mathrm{NO}_{3}\right)_{2} \\
40 \mathrm{~h}, 350{ }^{\circ} \mathrm{C}\end{array}$ & Columnar crystals & Structure determination & 43 \\
\hline $\mathrm{Ba}_{6}\left[\mathrm{~V}_{10} \mathrm{O}_{30}\left(\mathrm{H}_{2} \mathrm{O}\right)\right] \cdot 2.5 \mathrm{H}_{2} \mathrm{O}$ & $\begin{array}{l}\mathrm{NaVO}_{3} / \mathrm{BaI}_{2} / \mathrm{NMe}_{4} \mathrm{I} \\
40 \mathrm{~h}, 280^{\circ} \mathrm{C}\end{array}$ & Cubic single crystals & Structure determination & 44 \\
\hline
\end{tabular}

solutions is counterproductive, because starting materials with $\mathrm{X}: \mathrm{V}$-ratios of 1.1 and above frequently lead to the formation of microcrystalline, non-anisotropic vanadates and fluorovanadates instead of fibers with a high aspect ratio. The impact of the anions and of the cations can be summarized in "synthetic fields" 48 (Fig. 1), and representative morphologies are shown in Fig. 2. All in all, the $\mathrm{NaX} / \mathrm{V}_{2} \mathrm{O}_{5}(\mathrm{X}=\mathrm{OH}, \mathrm{F}-\mathrm{Br})$ and $\mathrm{LiOH} / \mathrm{V}_{2} \mathrm{O}_{5}$ 
A. Michailovski et al.: Hydrothermal synthesis of anisotropic alkali and alkaline earth vanadates

TABLE IV. Summary of experimental results (cf. Sec. III) on the hydrothermal formation of anisotropic alkali vanadates.

\begin{tabular}{|c|c|c|c|}
\hline Hydrothermal system & M:V-ratio & Morphology & Structure/phases \\
\hline $\begin{array}{l}\mathrm{LiOH} / \mathrm{V}_{2} \mathrm{O}_{5} \\
\mathrm{LiOH} / \mathrm{V}_{2} \mathrm{O}_{5} \\
\mathrm{LiX} / \mathrm{V}_{2} \mathrm{O}_{5}(\mathrm{X}=\mathrm{F}-\mathrm{I})\end{array}$ & $\begin{array}{l}0.1-0.8 \\
1.1 \\
0.1-0.8\end{array}$ & $\begin{array}{l}\text { Fibers, diameter } 400-600 \mathrm{~nm}, \mu \mathrm{m} \text {-scale lengths } \\
\text { Microscale crystals } \\
\text { Fibers, diameter } 400-600 \mathrm{~nm}, \mu \mathrm{m} \text {-scale lengths }\end{array}$ & $\begin{array}{l}\text { Fernandinite-related } \mathrm{Li}_{\mathrm{x}} \mathrm{V}_{2} \mathrm{O}_{5} \cdot \mathrm{nH}_{2} \mathrm{O} \\
\mathrm{Li}_{3} \mathrm{VO}_{4} \\
\text { Structurally related to } \mathrm{Li}_{\mathrm{x}} \mathrm{V}_{2} \mathrm{O}_{5} \cdot \mathrm{nH}_{2} \mathrm{O}\end{array}$ \\
\hline $\mathrm{NaX} / \mathrm{V}_{2} \mathrm{O}_{5}(\mathrm{X}=\mathrm{OH}, \mathrm{F})$ & $0.2-1.1$ & Fibers, diameter $\sim 400 \mathrm{~nm}, \mu \mathrm{m}$-scale lengths & Closely related to $\mathrm{Na}_{2} \mathrm{~V}_{6} \mathrm{O}_{16} \cdot 3 \mathrm{H}_{2} \mathrm{O}$ \\
\hline $\mathrm{NaOH} / \mathrm{V}_{2} \mathrm{O}_{5}$ & $>1.1$ & Microrods, diameter $\sim 5 \mu \mathrm{m}$, lengths up to $90 \mu \mathrm{m}$ & $\mathrm{Na}_{\mathrm{x}} \mathrm{V}_{2} \mathrm{O}_{5}$ \\
\hline $\mathrm{NaF} / \mathrm{V}_{2} \mathrm{O}_{5}$ & $>1.3$ & Rod-shaped microcrystals & $\mathrm{Na}_{3} \mathrm{VF}_{6}$ \\
\hline $\mathrm{NaCl} / \mathrm{V}_{2} \mathrm{O}_{5}$ & $1.1-1.5$ & Fibers, diameter $\sim 400 \mathrm{~nm}$, lengths of several $\mu \mathrm{m}$ & \\
\hline $\mathrm{NaBr} / \mathrm{V}_{2} \mathrm{O}_{5}$ & $0.4-0.8$ & Fibers, diameter $100-200 \mathrm{~nm}$, lengths up to $20 \mu \mathrm{m}$ & $\begin{array}{l}\text { Isostructural with bannermanite } \\
\qquad(\mathrm{Na}, \mathrm{K})_{\mathrm{x}} \mathrm{V}_{6} \mathrm{O}_{15}(0.5<\mathrm{x}<0.9)\end{array}$ \\
\hline $\mathrm{NaVO}_{3} / \mathrm{VOSO}_{4}$ & 0.7 & Fibers, diameter $50-150 \mathrm{~nm}$, several $\mu \mathrm{m}$ in length & \\
\hline $\mathrm{NaI} / \mathrm{V}_{2} \mathrm{O}_{5}$ & $0.4-0.8$ & Fibers, diameter $100-200 \mathrm{~nm}$, several $\mu \mathrm{m}$ in length & Unknown \\
\hline $\mathrm{NaI} / \mathrm{V}_{2} \mathrm{O}_{5}$ & $>1.1$ & Microrods & $\mathrm{Na}_{\mathrm{x}} \mathrm{V}_{2} \mathrm{O}_{5}$ \\
\hline $\mathrm{KX} / \mathrm{V}_{2} \mathrm{O}_{5}(\mathrm{X}=\mathrm{OH}, \mathrm{F}-\mathrm{I})$ & $0.2-1.1$ & Fibers with diameter of $100-400 \mathrm{~nm}$ and $\mu$-scale lengths & Mostly unknown phases \\
\hline $\mathrm{RbX} / \mathrm{V}_{2} \mathrm{O}_{5}(\mathrm{X}=\mathrm{OH}, \mathrm{F}-\mathrm{I})$ & $0.2-0.4$ & Microcrystals and rods (diameter $\sim 200 \mathrm{~nm}$ length $\sim 600 \mathrm{~nm}$ ) & Unknown phases and $\mathrm{RbV}_{3} \mathrm{O}_{8}$ \\
\hline $\begin{array}{l}\mathrm{CsX} / \mathrm{V}_{2} \mathrm{O}_{5}(\mathrm{X}=\mathrm{OH}, \mathrm{F}-\mathrm{I}) \\
\mathrm{CsF} / \mathrm{V}_{2} \mathrm{O}_{5}\end{array}$ & $\begin{array}{l}0.2-0.8 \\
>0.4\end{array}$ & $\begin{array}{l}\text { Microcrystals and rods (diameter } 200-500 \mathrm{~nm} \text {, length } 1-3 \mu \mathrm{m} \text { ) } \\
\mu \mathrm{m} \text {-size crystals }\end{array}$ & $\begin{array}{l}\text { Unknown phases }+\mathrm{CsV}_{3} \mathrm{O}_{8} \\
\mathrm{Cs}_{3} \mathrm{~V}_{2} \mathrm{O}_{4} \mathrm{~F}_{5}\end{array}$ \\
\hline
\end{tabular}

TABLE V. Summary of experimental results (cf. Sec. III) on the hydrothermal formation of anisotropic alkaline earth vanadates.

\begin{tabular}{|c|c|c|c|}
\hline Hydrothermal system & M:V-ratio & Morphology & Structure/phases \\
\hline $\mathrm{Mg}(\mathrm{OH})_{2} / \mathrm{V}_{2} \mathrm{O}_{5}$ & $0.2-0.4$ & Fibers: diameter $300-500 \mathrm{~nm}$, length $30 \mu \mathrm{m}$ and above & Unknown phase \\
\hline $\mathrm{Mg}(\mathrm{OH})_{2} / \mathrm{V}_{2} \mathrm{O}_{5}$ & 0.75 & Flower-like needle patterns $(\sim 5 \times 130 \mu \mathrm{m})$ & $" \mathrm{Mg}_{7-\mathrm{x}}\left(\mathrm{VO}_{4}\right)_{4}(\mathrm{OH})_{3} "$ \\
\hline $\mathrm{Sr}(\mathrm{OH})_{2} / \mathrm{V}_{2} \mathrm{O}_{5}$ & $0.2-0.3$ & Fibers: diameter $100-200 \mathrm{~nm}$, length $30 \mu \mathrm{m}$ and above & Unknown phase \\
\hline $\mathrm{Sr}(\mathrm{OH})_{2} / \mathrm{V}_{2} \mathrm{O}_{5}$ & $>0.3$ & Fibers: diameter $300-2 \mu \mathrm{m}$, length $20 \mu \mathrm{m}$ in length & $\beta-\mathrm{SrV}_{2} \mathrm{O}_{6}$ (+ unknown phase) \\
\hline $\mathrm{Ba}(\mathrm{OH})_{2} / \mathrm{V}_{2} \mathrm{O}_{5}$ & $<0.4$ & Fibers: diameter $200-500 \mathrm{~nm}$, several $\mu \mathrm{m}$ in length & Related to $\mathrm{Ba}_{0.97}\left(\mathrm{~V}_{6} \mathrm{O}_{16}\right)\left(\mathrm{H}_{2} \mathrm{O}\right)_{1.67}$ \\
\hline $\mathrm{Ba}(\mathrm{OH})_{2} / \mathrm{V}_{2} \mathrm{O}_{5}$ & $0.4-0.8$ & Fibers: diameter $150-200 \mathrm{~nm}$, up to $5 \mu \mathrm{m}$ in length & catena $-\mathrm{Ba}\left(\mathrm{VO}_{3}\right)_{2} \cdot 2 \mathrm{H}_{2} \mathrm{O}$ \\
\hline
\end{tabular}

TABLE VI. Synthetic profiles of the alkali cations in the hydrothermal synthesis of anisotropic vanadates.

\begin{tabular}{lcc}
\hline \hline Cation & Typical products & Characteristic morphology \\
\hline $\mathrm{Li}^{+}$ & $\begin{array}{c}\text { Layered lithium vanadates } \\
\text { (mineral-related: }\end{array}$ & $\begin{array}{c}\text { Anisotropic, fibrous } \\
\text { products }\end{array}$ \\
& fernandinite) \\
$\mathrm{Na}^{+}$ & $\begin{array}{c}\text { Mineral-related phases } \\
\text { (barnesite/bannermanite) }\end{array}$ & $\begin{array}{c}\text { Anisotropic, fibrous } \\
\text { products }\end{array}$ \\
$\mathrm{K}^{+}$ & $\begin{array}{c}\text { Unknown potassium } \\
\text { vanadates }\end{array}$ & Fibrous, less anisotropic \\
$\mathrm{Rb}^{+}, \mathrm{Cs}^{+}$ & $\begin{array}{c}\text { Unknown phases and } \\
\text { microcrystalline } \\
\text { polyoxovanadates }\end{array}$ & $\begin{array}{c}\text { Microcrystals, low } \\
\text { degree of anisotropy }\end{array}$ \\
& & \\
\hline \hline
\end{tabular}

hydrothermal systems (cf. highlighted part of Fig. 1) exhibit the strongest tendency toward the formation of highly anisotropic and phase pure fibers among the systems investigated in this study. Therefore, they are discussed in detail in Secs. III. B and III. C.

Although the $\mathrm{KX} / \mathrm{V}_{2} \mathrm{O}_{5}(\mathrm{X}=\mathrm{OH}, \mathrm{F}-\mathrm{I})$ systems provide access to a broad spectrum of anisotropic potassium vanadates, they will not be discussed in detail because the majority of the products have not been structurally characterized up to now due to the difficulties outlined below for the LiOH/ $/ \mathrm{V}_{2} \mathrm{O}_{5}$ system (cf. Sec. III. B).
The same applies for the rubidium- and cesium-based systems when combined with the softer halides $\left(\mathrm{Cl}^{-}-\mathrm{I}^{-}\right)$. Unlike their lithium- and sodium-based analogues, the $\mathrm{MX} / \mathrm{V}_{2} \mathrm{O}_{5}(\mathrm{M}=\mathrm{Rb}, \mathrm{Cs} ; \mathrm{X}=\mathrm{OH}, \mathrm{F})$ systems exhibit a low tendency toward vanadate fiber growth, and microcrystalline $\mathrm{MV}_{3} \mathrm{O}_{8}(\mathrm{M}=\mathrm{Rb}, \mathrm{Cs})$ vanadates are often formed instead (Fig. 2, bottom, left). Furthermore, mmsized crystals of fluorovanadates, such as $\mathrm{Cs}_{3} \mathrm{~V}_{2} \mathrm{O}_{4} \mathrm{~F}_{5},{ }^{49}$ emerge from $\mathrm{F}$ : V-ratios above 1.1. As the known synthetic routes to fluorovanadates may require several synthetic steps including the use of $\mathrm{HF},{ }^{50}$ their one-step hydrothermal preparation from the alkali fluorides and $\mathrm{V}_{2} \mathrm{O}_{5}$ is a convenient preparative alternative.

\section{B. Fibrous lithium vanadates in the $\mathrm{LiX} / \mathrm{V}_{2} \mathrm{O}_{5}$ ( $X=\mathrm{OH}, \mathrm{F}-\mathrm{I}$ ) hydrothermal systems}

Among the various types of lithium vanadate fibers resulting from the hydrothermal reaction of $\mathrm{V}_{2} \mathrm{O}_{5}$ in $\mathrm{LiX}$ $(\mathrm{X}=\mathrm{OH}, \mathrm{F}-\mathrm{I})$ solutions, the products grown in the presence of $\mathrm{LiOH}$ exhibit the highest degree of crystallinity and anisotropy. The lithium vanadate rods exhibit average diameters in the range of $400-600 \mathrm{~nm}$ and lengths extending up to several micrometers (cf. Fig. 3 and Table IV). They are formed within a specific 


\begin{tabular}{|c|c|c|c|c|}
\hline & $\mathrm{HO}^{-}$ & $\mathrm{Cl}^{-}$ & $\mathrm{Br}^{-}$ & I \\
\hline $\begin{array}{l}\mathrm{L}^{+} \\
\mathrm{Na}^{+}\end{array}$ & $\begin{array}{l}\text { Vanadate } \\
\text { rods with } \\
\text { high aspect } \\
\text { ratio }\end{array}$ & & & \\
\hline $\mathbf{K}^{+}$ & \multicolumn{4}{|c|}{ Rods with mostly unknown structures } \\
\hline $\begin{array}{l}\mathrm{Rb}^{+} \\
\mathrm{Cs}^{+}\end{array}$ & & & $\begin{array}{r}\text { Forma } \\
\text { nanoplat } \\
\text { microc }\end{array}$ & $\begin{array}{l}\text { of } \\
\text { and } \\
\text { als }\end{array}$ \\
\hline
\end{tabular}

FIG. 1. Synthetic trends in the alkali halide/hydroxide-assisted hydrothermal preparation of anisotropic vanadates: the $\mathrm{MX} / \mathrm{V}_{2} \mathrm{O}_{5}(\mathrm{M}=\mathrm{Li}$, $\mathrm{Na} ; \mathrm{X}=\mathrm{OH}, \mathrm{F}$ ) hydrothermal systems (highlighted in the upper left area) afford vanadate fibers with the highest aspect ratios.

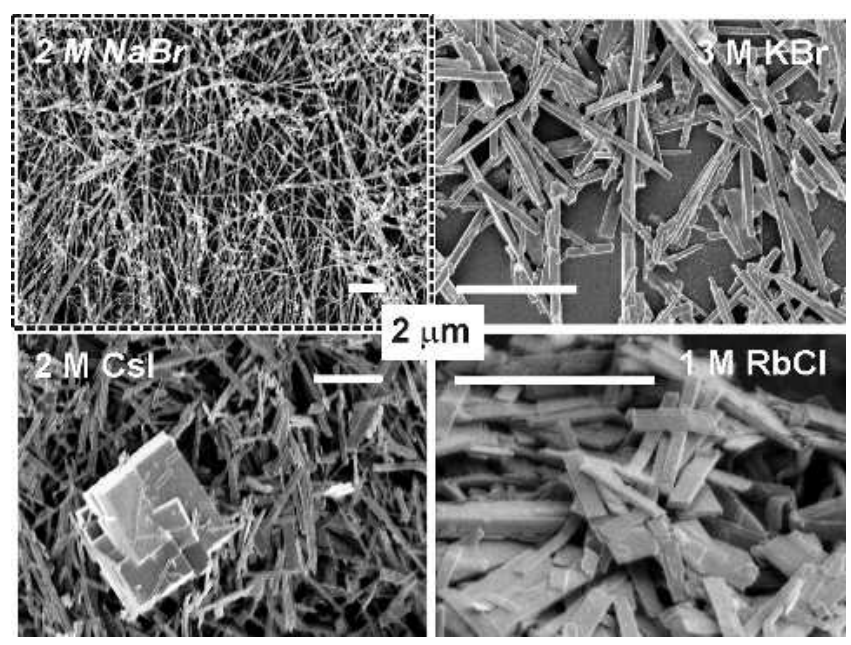

FIG. 2. Representative morphologies of anisotropic vanadates obtained in the hydrothermal $\mathrm{MX} / \mathrm{V}_{2} \mathrm{O}_{5}(\mathrm{M}=\mathrm{Na}-\mathrm{Cs} ; \mathrm{X}=\mathrm{OH}$, $\mathrm{F}-\mathrm{I}$ ) systems (clockwise): $\mathrm{MX}=\mathrm{NaBr}$ (bannermanite fibers), $\mathrm{KBr}$ $\left(\mathrm{KV}_{3} \mathrm{O}_{8}\right.$ fibers), $\mathrm{RbCl}$ and $\mathrm{CsI}$ (vanadates with a hitherto unidentified crystal structure).

parameter window: the $\mathrm{Li}: \mathrm{V}$-ratio in the starting material must be adjusted between values of 0.05 and 0.75 under the standard hydrothermal conditions outlined above (cf. Sec. II). The lithium content in the products increases accordingly from 2 at. $\%$ to 22 at.\%. The x-ray diffraction (XRD) patterns of this series of fibrous lithium vanadates, $\mathrm{Li}_{\mathrm{x}} \mathrm{V}_{2} \mathrm{O}_{5} \cdot \mathrm{nH}_{2} \mathrm{O}$, are related to that of the mineral fernandinite $\left(\mathrm{Ca}_{1.44}\left(\mathrm{~V}_{7.6} \mathrm{Fe}_{0.4} \mathrm{O}_{20}\right)\left(\mathrm{H}_{2} \mathrm{O}\right)_{4}\right){ }^{51}$ Fig. 4(a) displays the representative XRD pattern [Fig. 4(a3)] of the lithium vanadate fibers emerging from an initial Li:V-ratio of 0.38 together with the data for fernandinite [Fig. 4(a-1)]. Both compounds have a similar $\mathrm{V}_{2} \mathrm{O}_{5}$ layer structure in common [Fig. 4(b)] and the cations and crystal water molecules are located between the layers.
An approximate structural model was derived from powder diffraction data for $\mathrm{Li}_{\mathrm{x}} \mathrm{V}_{2} \mathrm{O}_{5} \cdot \mathrm{nH}_{2} \mathrm{O}$ starting from the fernandinite structure. ${ }^{51}$ The double layers of edgeand corner-sharing $\mathrm{VO}_{5}$ pyramids present in fernandinite were generated for the triclinic cell $[P-1 ; \mathrm{a}=6.111(5)$ $\AA, b=10.493(5) \AA, c=3.643(5) \AA, \alpha=94.8(2)^{\circ}$, $\left.\beta=106.7(2)^{\circ}, \gamma=94.0(2)^{\circ}\right]$. Whereas a free refinement was possible for the vanadium positions, the low data/parameter ratio did not permit a Rietveld refinement where all atom positions were refined freely.

Therefore, the oxygen positions were subsequently adjusted on the basis of the bond distances and angles observed for fernandinite, and the calculated powder diffraction patterns were checked against the experimental data. The lithium position was determined from difference electron density maps, but its overall influence on the approximate model is too low to assign the precise lithium content. As a consequence, the oxidation state of the vanadium atoms remains unknown. This preliminary model cannot substitute a precise structure determination from single crystal data. However, the calculated powder data [Fig. 4 (a-2)] shows that it is a reasonable representation of the structural motif present in $\mathrm{Li}_{\mathrm{x}} \mathrm{V}_{2} \mathrm{O}_{5} \cdot \mathrm{nH}_{2} \mathrm{O}$. It is furthermore analogous to synthetic $\delta-\mathrm{Ag}_{0.68} \mathrm{~V}_{2} \mathrm{O}_{5}$, and it occurs in the "straczekite group" of natural vanadium bronzes as well. ${ }^{52}$

The strong influence of hydrothermal parameter shifts on the resulting type of lithium vanadate fibers is shown in Fig. 3 for variations of the standard procedure for $\mathrm{Li}_{\mathrm{x}} \mathrm{V}_{2} \mathrm{O}_{5} \cdot \mathrm{nH}_{2} \mathrm{O}$ fiber formation [6 days of hydrothermal treatment at $180{ }^{\circ} \mathrm{C}$ starting from a Li:V-ratio of 0.38 , cf. Fig. 3(e)]. The timescale of the reaction appears to be rather slow when compared with the minute-scale hydrothermal production of $\mathrm{MoO}_{3}$ rods: ${ }^{3}$ after $4 \mathrm{~h}$ of hydrothermal treatment at $180^{\circ} \mathrm{C}, \mathrm{V}_{2} \mathrm{O}_{5}$ is transformed into a structurally amorphous fibrous intermediate [Fig. 3(b)], and at least 1-2 days of reaction time are required for the conversion into crystalline fibers. Prolonged reaction times (18 days) lead to an increase in anisotropy of the fibers [Fig. 3(d)]; while their diameters remain in the $100-300 \mathrm{~nm}$ range, their lengths are $30 \mu \mathrm{m}$ and higher. However, their XRD pattern could not be assigned to a known vanadate type up to now. Fiber formation sets in around $100{ }^{\circ} \mathrm{C}$ [Fig. 3(a)]. At $140{ }^{\circ} \mathrm{C}$, fibers with an exceptionally high aspect ratio (diameters around $300 \mathrm{~nm}$ and lengths up to $140 \mu \mathrm{m}$ ) and a hitherto unknown XRD pattern are formed. An increase of the starting Li:V-ratio from 0.38 to 0.56 leads to further alterations of the XRD patterns, and higher $\mathrm{LiOH}$ concentrations favor the growth of microcrystalline $\mathrm{Li}_{3} \mathrm{VO}_{4}$ [Fig. 3(c)]. ${ }^{53}$

The fernandinite-related fibers were heated for 3 days at $180{ }^{\circ} \mathrm{C}$ in air. Although this leads to a loss of crystalline water, both the morphology and the structural motif of the fibers are maintained.

This renders them suitable for applications at elevated 


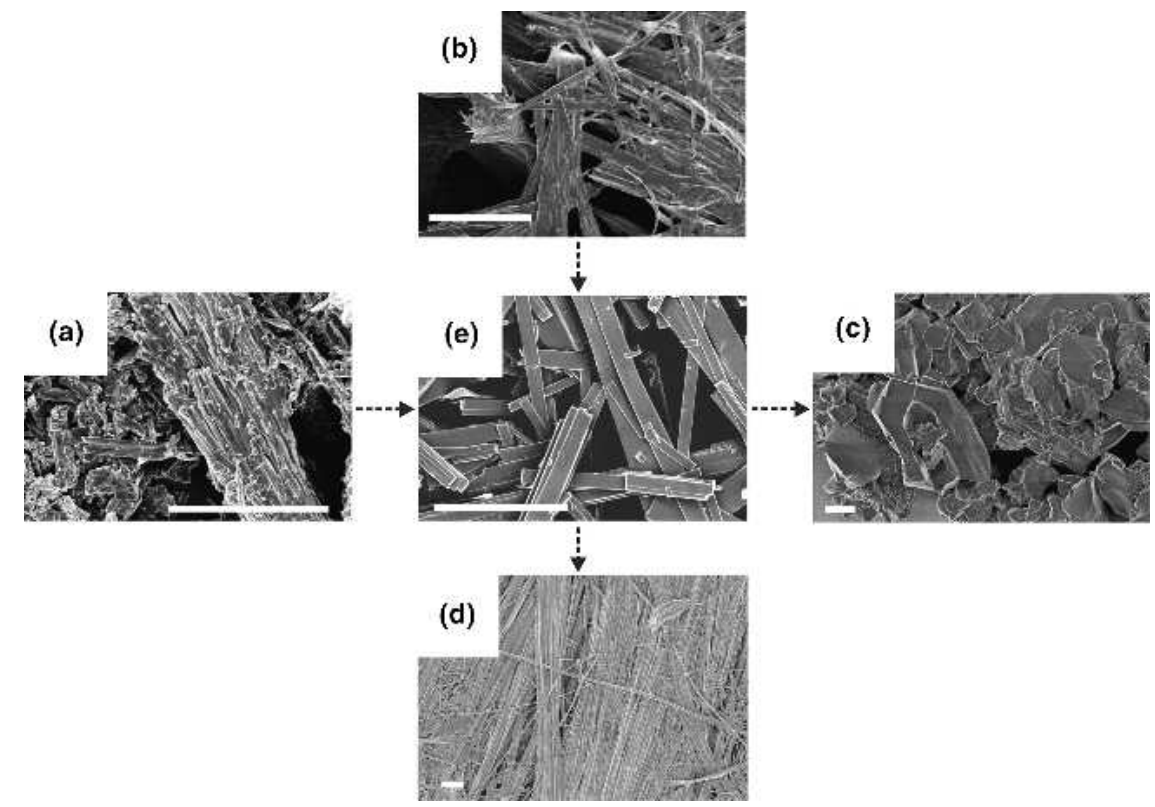

FIG. 3. SEM images (scale bar $=3 \mu \mathrm{m}$ ) demonstrating the influence of the hydrothermal parameter variations (a-d) on the morphology of lithium vanadate fibers compared with the products obtained under standard conditions [initial Li:V-ratio $=0.38,6$ days, $180^{\circ} \mathrm{C}$, (e)]: (a) deteriorated morphology obtained at $100{ }^{\circ} \mathrm{C}$; (b) amorphous fibers grown after $4 \mathrm{~h}$ of reaction time; (c) microcrystalline $\mathrm{Li}_{3} \mathrm{VO}_{4}$ formed from an initial Li:V-ratio of 1.1; (d) fibers with a high aspect ratio grown after 18 days.

temperatures. Further investigations concerning their lithium intercalation behavior are under way.

In summary, the hydrothermal system $\mathrm{LiOH} / \mathrm{V}_{2} \mathrm{O}_{5}$ exhibits the following synthetic characteristics:

(i) The lithium cation is readily incorporated to form a multitude of fibrous vanadates with diameters between 100 and $400 \mathrm{~nm}$ and lengths in the micrometer range.

(ii) Among this product spectrum, a careful parameter adjustment is required to address a specific vanadate phase.

(iii) The majority of the products are closely related to the mineral fernandinite, but the high anisotropy of the fibers renders precise structure determinations from powder data extremely difficult.

This applies for the remaining $\mathrm{MX} / \mathrm{V}_{2} \mathrm{O}_{5}(\mathrm{M}=\mathrm{Na}-$ Cs; $\mathrm{X}=\mathrm{OH}, \mathrm{F}-\mathrm{I}$ ) systems as well. Therefore, only the major preparative trends emerging from extensive screening studies in the sodium-based systems are summarized in the following section (cf. Table IV and Sec. III. C.).

\section{Formation of barnesite-related vanadate fibers in the $\mathrm{NaX} / \mathrm{V}_{2} \mathrm{O}_{5}$ systems $(\mathrm{X}=\mathrm{OH}, \mathrm{F})$}

The hydrothermal reaction of $\mathrm{V}_{2} \mathrm{O}_{5}$ with solutions of $\mathrm{NaOH}$ and $\mathrm{NaF}$ affords sodium vanadate rods after

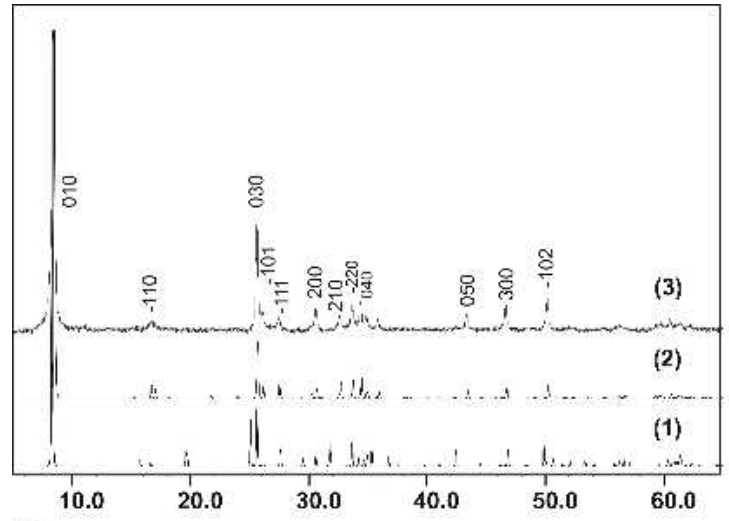

(a)

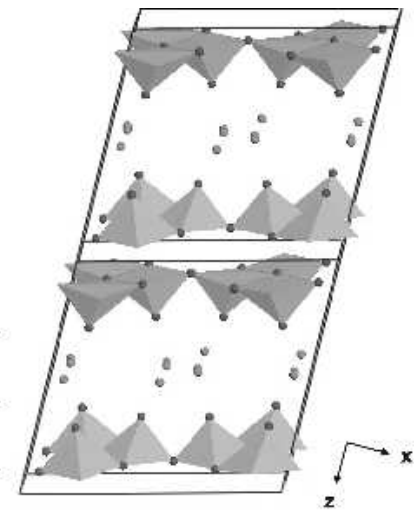

(b)

FIG. 4. (a) Theoretical powder data for fernandinite (1) and for the structural model derived for $\mathrm{Li}_{\mathrm{x}} \mathrm{V}_{2} \mathrm{O}_{5} \cdot \mathrm{nH}_{2} \mathrm{O}$ (2) together with the experimental data for $\mathrm{Li}_{\mathrm{x}} \mathrm{V}_{2} \mathrm{O}_{5} \cdot \mathrm{nH}_{2} \mathrm{O}$ (3). (b) Structural model for $\mathrm{Li}_{\mathrm{x}} \mathrm{V}_{2} \mathrm{O}_{5} \cdot \mathrm{nH}_{2} \mathrm{O}$ : the lithium cations are intercalated between double layers of corner-sharing $\mathrm{VO}_{5}$ pyramids (gray sheets). 


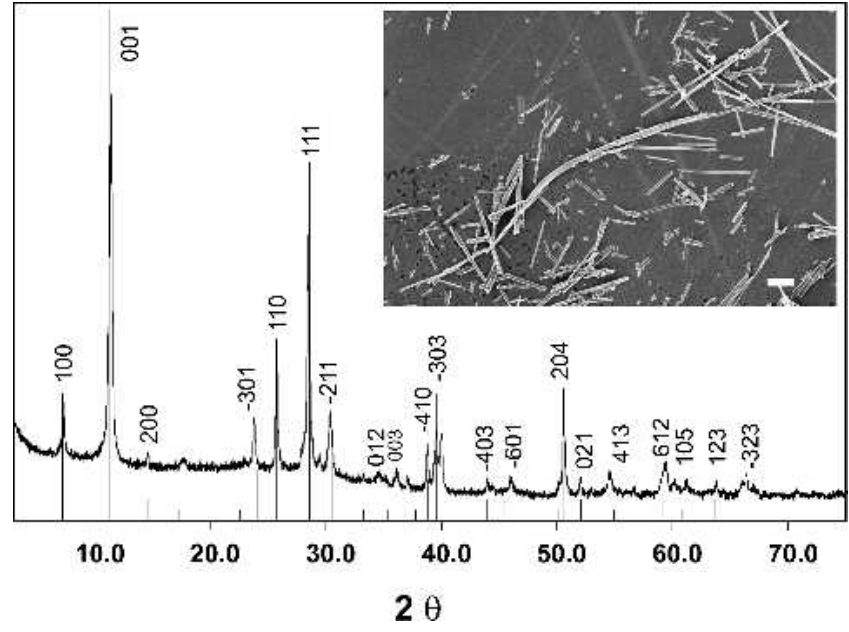

FIG. 5. XRD pattern and representative SEM image (inset) of barnesite rods generated in the hydrothermal system $\mathrm{NaF} / \mathrm{V}_{2} \mathrm{O}_{5}$ compared with the JCPDS data for barnesite (16-601).

6 days of treatment at $180{ }^{\circ} \mathrm{C}$. The fibers display diameters around $400 \mathrm{~nm}$ and microscale lengths up to $30 \mu \mathrm{m}$ and above (Fig. 5). They are formed within a wide Na:Vrange of $0.2-1.1$. The highly anisotropic sodium vanadate fibers are structurally closely related to the natural mineral barnesite, $\mathrm{Na}_{2} \mathrm{~V}_{6} \mathrm{O}_{16} \cdot 3 \mathrm{H}_{2} \mathrm{O}$ (Fig. 5). ${ }^{54}$

Their lattice constants [monoclinic, $\mathrm{a}=12.18(4) \AA$, $\left.\mathrm{b}=3.610(8) \AA, c=7.80(1) \AA, \beta=95.3(2)^{\circ}\right]$ agree well with the literature data for barnesite $(P 2 / m, \mathrm{a}=$ $\left.12.17 \AA, b=3.602 \AA, c=7.78 \AA, \beta=95.03^{\circ}\right) .{ }^{54}$ Barnesite is a member of the hewettite mineral family with the general composition $\mathrm{M}_{2} \mathrm{~V}_{6} \mathrm{O}_{16} \cdot \mathrm{nH}_{2} \mathrm{O}$ ( $\mathrm{M}=$ monovalent) or $\mathrm{MV}_{6} \mathrm{O}_{16} \cdot \mathrm{nH}_{2} \mathrm{O}(\mathrm{M}=$ divalent $){ }^{55}$

The hewettite minerals have $\mathrm{V}_{6} \mathrm{O}_{16}$ layers with interlayer metal atoms as a structural motif in common. ${ }^{41}$ The $\mathrm{V}_{6} \mathrm{O}_{16}$ layers consist of double layers of edge-sharing $\mathrm{VO}_{6}$ octahedra that are linked to a single chain of edgesharing $\mathrm{VO}_{5}$ trigonal bipyramids. This structural motif is present in $\mathrm{Li}_{1+\mathrm{x}} \mathrm{V}_{3} \mathrm{O}_{8}$ as well that has recently attracted interest as a promising cathode material. ${ }^{56,57}$

The present hydrothermal approach provides a onestep access to gram amounts of sodium hewettite fibers for the study of their reactivity and properties. Although the hewettite series has already been named in 1914, more than 80 years passed by until the first complete structural analysis of a hewettite mineral was published in 1998 with the crystal structure determination of synthetic barium hewettite. ${ }^{41}$ These difficulties in assigning a structural motif to the hewettites were caused by the tendency of the natural minerals to grow as silky fibers that are too small for single crystal analysis. ${ }^{58}$ The same problem also applies for most of the novel fibrous alkali vanadates obtained in the course of this study.

As has been observed for the lithium-based systems, a further increase of the Na:V-ratio in the starting material leads to the formation of microcrystalline phases (e.g., $\mathrm{Na}_{2} \mathrm{~V}_{6} \mathrm{O}_{16}{ }^{59}$ ) with no special morphological features and to fluorination reactions $\left(\mathrm{Na}_{3} \mathrm{VF}_{6}{ }^{60}\right)$.

\section{Formation of bannermanite-related vanadate fibers in the $\mathrm{NaX} / \mathrm{V}_{2} \mathrm{O}_{5}$ systems $(\mathrm{X}=\mathrm{Cl}, \mathrm{Br})$}

The formation of sodium vanadate fibers in the $\mathrm{NaX} /$ $\mathrm{V}_{2} \mathrm{O}_{5}(\mathrm{X}=\mathrm{Cl}, \mathrm{Br})$ systems differs considerably from the analogous fluoride- and hydroxide-based systems. This illustrates the influence of the anions (and of the $\mathrm{pH}$ in hydroxide systems) on the synthetic process.

Whereas the Na:V-ratio in the starting material can be widely varied for the growth of barnesite-related fibers, the concentration of the $\mathrm{NaCl}$ and $\mathrm{NaBr}$ additive solutions must be adjusted more carefully to obtain fibrous products: for 6 days of hydrothermal treatment at $180^{\circ} \mathrm{C}$, the respective $\mathrm{Na}: \mathrm{V}$-parameter windows are $0.4-0.75$ for $\mathrm{NaBr}$ and 1.1-1.5 for $\mathrm{NaCl}$. As has been observed for the $\mathrm{NaOH}-$ and $\mathrm{NaF} / \mathrm{V}_{2} \mathrm{O}_{5}$ systems, the formation of fibrous vanadates in the $\mathrm{NaBr} / \mathrm{V}_{2} \mathrm{O}_{5}$ system discontinues at $\mathrm{Na}: \mathrm{V}$-ratios of 2 and above so that microcrystals of $\mathrm{NaV}_{6} \mathrm{O}_{15}{ }^{59}$ are formed in the presence of hitherto unidentified phases.

The aspect ratio of the sodium vanadate fibers depends on the anion: $\mathrm{NaCl}$ affords fibers with maximum diameters of $400 \mathrm{~nm}$ and lengths of several micrometers, whereas the use of $\mathrm{NaBr}$ reduces the average fiber diameter to $100-200 \mathrm{~nm}$, accompanied by fiber lengths up to $20 \mu \mathrm{m}$. The starting material is quantitatively converted into a fine cobweb of sodium vanadate rods (Fig. 6). These fibers [monoclinic, $\mathrm{a}=15.417(5) \AA, \mathrm{b}=$ 3.614(1) $\left.\AA, c=10.094(3) \AA, \beta=109.47(3)^{\circ}\right]$ are isostructural with the natural mineral bannermanite $[C 2 / m$,

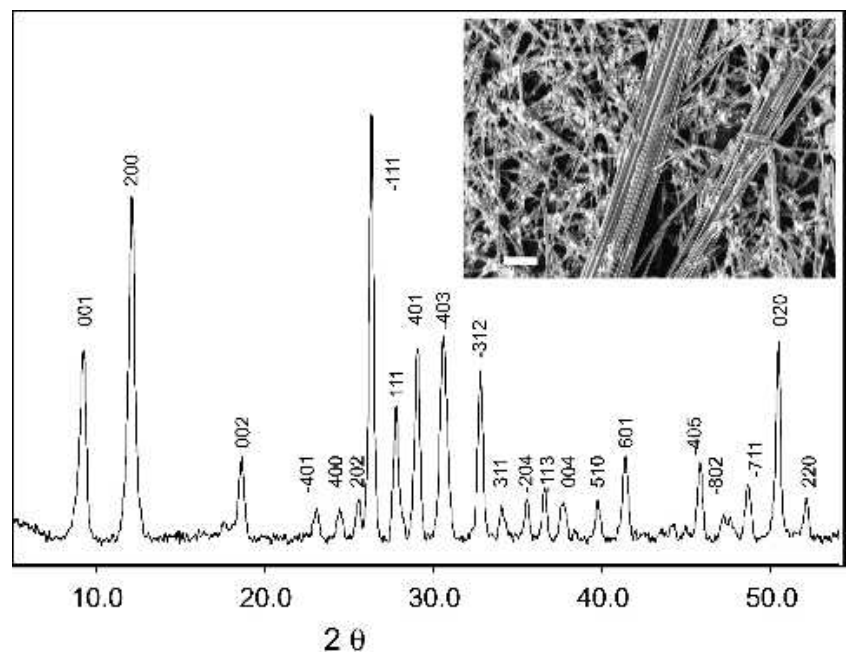

FIG. 6. XRD pattern and representative SEM image (inset, scale bar $=1 \mu \mathrm{m}$ ) of bannermanite rods grown in the hydrothermal system $\mathrm{NaBr} / \mathrm{V}_{2} \mathrm{O}_{5}$. 
$\mathrm{a}=15.413(7) \AA, \mathrm{b}=3.615(2) \AA, \mathrm{c}=10.066(8) \AA$, $\beta=109.29(8)^{\circ}$ ] (Fig. 6). ${ }^{61}$ Natural bannermanite is represented by the general formula $(\mathrm{Na}, \mathrm{K})_{\mathrm{x}} \mathrm{V}^{4+}{ }_{\mathrm{x}} \mathrm{V}^{5+}{ }_{6-\mathrm{x}} \mathrm{O}_{15}$ $(0.54<\mathrm{x}<0.90)$, and it is isostructural with $\beta-\mathrm{Na}_{\mathrm{x}} \mathrm{V}_{6} \mathrm{O}_{15}$. Both compounds exhibit a $3 \mathrm{D}$ bronze framework consisting of zigzag sheets of distorted $\mathrm{VO}_{6}$ octahedra that are linked through two square-based pyramids sharing edges. ${ }^{62}$ The sodium sites in bannermanite display a unique 7 -fold coordination that has only been found in six other minerals before. ${ }^{62}$ The hydrothermal formation of the bannermanite tunnel structure under the given conditions requires the presence of chloride and bromide anions in the reaction medium, whereas the use of sodium fluoride solutions clearly favors the formation of the layered barnesite type (cf. Sec. III. C). ${ }^{55}$ Interestingly, the hydrothermal treatment of molybdenum(VI)precursor materials in alkali halide solutions exhibits a similar influence of the anions on the crystal structure of the resulting molybdates: when chloride and bromide solutions are used, hexagonal molybdate phases with a 3D channel structure are preferably formed, while fluoride solutions favor different product types. ${ }^{46}$

Finally, the $\mathrm{NaI} / \mathrm{V}_{2} \mathrm{O}_{5}$ system affords fibrous materials with diameters between 100 and $200 \mathrm{~nm}$ and microscale lengths when the Na:V-ratio in the starting material is adjusted between 0.4 and 1.3. Unlike the products obtained from the $\mathrm{NaCl}$-and $\mathrm{NaBr} / \mathrm{V}_{2} \mathrm{O}_{5}$ systems, these fibers do not bear resemblance to known types of vanadates. In summary, the synthetic profiles of the $\mathrm{NaX} / \mathrm{V}_{2} \mathrm{O}_{5}$-systems vary with increasing polarizability of the anion from $\mathrm{X}=\mathrm{F} / \mathrm{OH}$ over $\mathrm{X}=\mathrm{Cl} / \mathrm{Br}$ to $\mathrm{X}=\mathrm{I}$ (Table IV).

The hydrothermal systems $\mathrm{NaX} / \mathrm{V}_{2} \mathrm{O}_{5}(\mathrm{X}=\mathrm{Cl}, \mathrm{Br})$ provide access to gram-scale quantities of sodium bannermanite fibers in a single reaction step. However, they can alternatively be accessed through a two-step reaction sequence that illustrates the sensitivity of vanadiumbased systems toward hydrothermal parameter shifts. In the first step, a precursor solution was prepared from $\mathrm{NaVO}_{3}$ and $\mathrm{VOSO}_{4}$, followed by 2 days of hydrothermal treatment at $220^{\circ} \mathrm{C}$. The "preparative history" of the precursor solution determines the course of the reaction: a solution of $\mathrm{NaVO}_{3}$ must be slowly added to a $\mathrm{VOSO}_{4}$ solution so that the subsequent hydrothermal treatment quantitatively converts the precursor [Fig. 7(a)] into bannermanite fibers with diameters between 50 and $150 \mathrm{~nm}$ and microscale lengths [Fig. 7(b)]. When the precursor solution is synthesized in reverse order, the hydrothermal treatment fails to bring forward highly fibrous materials in quantitative fashion [Fig. 7(c)]. This unexpected result outlines how the complex polyoxovanadate equilibria in solution influence the morphology of the final product. ${ }^{63}$ Therefore, the one-step hydrothermal approach towards bannermanite fibers is more robust and requires less preparative precautions.

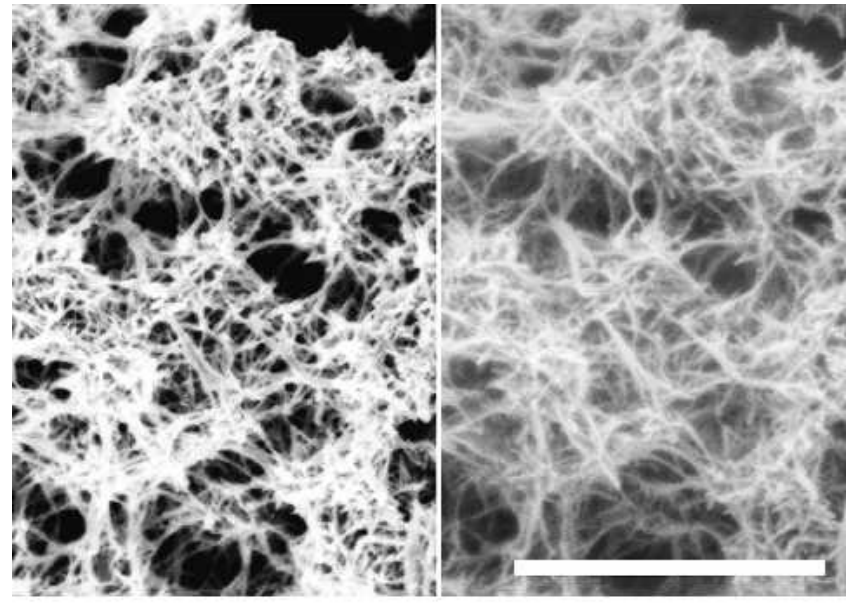

(a)
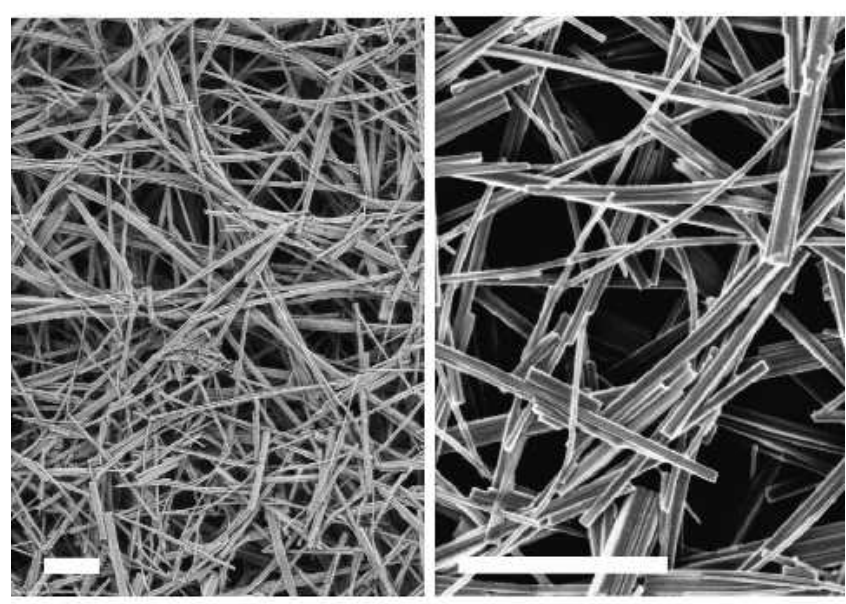

(b)

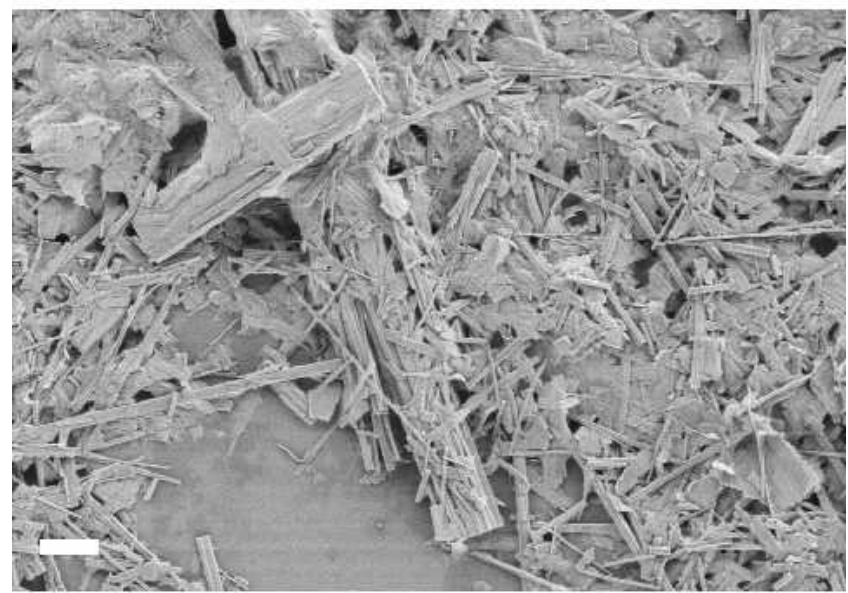

(c)

FIG. 7. SEM images (scale bar $=1 \mu \mathrm{m}$ ) monitoring the influence of the reaction parameters on the hydrothermal formation of bannermanite fibers: (a) precursor material precipitated at room temperature through the addition of $\mathrm{NaVO}_{3}$ to a $\mathrm{VOSO}_{4}$ solution, (b) bannermanite fibers obtained after hydrothermal treatment of the precursor material ( 2 days, $220^{\circ} \mathrm{C}$ ), (c) deteriorated morphology obtained from the hydrothermal treatment of a precursor material prepared in reverse order (addition of $\mathrm{VOSO}_{4}$ to $\mathrm{NaVO}_{3}$ ). 


\section{RESULTS: HYDROTHERMAL SYNTHESIS OF ANISOTROPIC ALKALINE EARTH VANADATES}

The synthetic trends among the hydrothermal systems $\mathrm{MX}_{2} / \mathrm{V}_{2} \mathrm{O}_{5}(\mathrm{M}=\mathrm{Mg}-\mathrm{Ba} ; \mathrm{X}=\mathrm{OH}, \mathrm{Cl})$ are closely related to the alkali halide/hydroxide-based systems: starting materials with $\mathrm{M}: \mathrm{V}$-values within a specific parameter window (usually between 0.2 and 0.5 ) afford fibrous vanadates, whereas higher $\mathrm{M}: \mathrm{V}$-ratios promote the growth of isotropic microcrystals. Similar to the fibrous alkali vanadates, the structural motifs of the alkaline earth vanadate fibers are difficult to assign. Therefore, only the most interesting results among the $\mathrm{M}(\mathrm{OH})_{2} / \mathrm{V}_{2} \mathrm{O}_{5}(\mathrm{M}=\mathrm{Mg}-\mathrm{Ba})$ systems are presented in the following (cf. Table V).

\section{A. Anisotropic vanadates in the $\mathrm{Mg}(\mathrm{OH})_{2} /$ $\mathrm{V}_{2} \mathrm{O}_{5}$ system}

The hydrothermal treatment of $\mathrm{V}_{2} \mathrm{O}_{5}$ under standard conditions (cf. Sec. II) starting from Mg:V-ratios of 0.20.4 leads to the formation of fibrous magnesium vanadates with diameters around 300-500 nm and lengths up to $30 \mu \mathrm{m}$ and above (Fig. 8).

When the Mg:V-ratio in the educt is raised to 0.75 , the formation of fibrous products discontinues and an entirely different product type is obtained instead: a magnesium vanadate with a hierarchical, flower-like growth pattern (Fig. 9). The stem of the particles is about $40 \mu \mathrm{m}$ in diameter and $60 \mu \mathrm{m}$ in length. A half-sphere of needles (about $130 \times 5 \mu \mathrm{m}$ ) emerges from the stem with a regularity that reminds of biomimetic growth patterns. When the synthesis is performed at $220^{\circ} \mathrm{C}$ for 17 days, the flower stem adopts a regular, hexagonal shape [Fig. 9(a)]. This morphology reflects the hexagonal structure determined from synchrotron $x$-ray powder diffraction data (cf. Sec. II). The diffraction data were indexed with the program DICVOL04 (figure of merit M(19) = 671) in a hexagonal cell with the cell parameters 12.908(1) $\AA$ and 5.084(1) $\AA$. A database search has provided zinc hydroxide sulfate vanadate $(\mathrm{V})\left[\mathrm{Zn}_{7}(\mathrm{OH})_{3}\left(\mathrm{SO}_{4}\right)\left(\mathrm{VO}_{4}\right)_{3}\right.$; $\left.P 6_{3} m c, a=12.813(1) \AA, c=5.143(1) \AA\right]$ as a structural model for the refinement. ${ }^{64}$ The Rietveld refinement (done with the program Fullprof ${ }^{65}$ ) has been carried out in the space group $\mathrm{P}_{3} m c$, allowing for all the unit cell constants, necessary profile parameters, and all the atomic positional and thermal parameters to vary. One of the two different magnesium positions is certainly incompletely occupied, thus leading to the chemical formula $\mathrm{Mg}_{7-\mathrm{x}}\left(\mathrm{VO}_{4}\right)_{4}(\mathrm{OH})_{3}$ so that the formal electro-neutrality of the chemical formula is not obeyed. However, the difference Fourier maps did not show any additional maxima that were not accounted for in the model, thus proving the original structure motif to be correct [Fig. 9(c)]. The weak scattering power of oxygen and hydrogen compared with that of the metal ions, as well

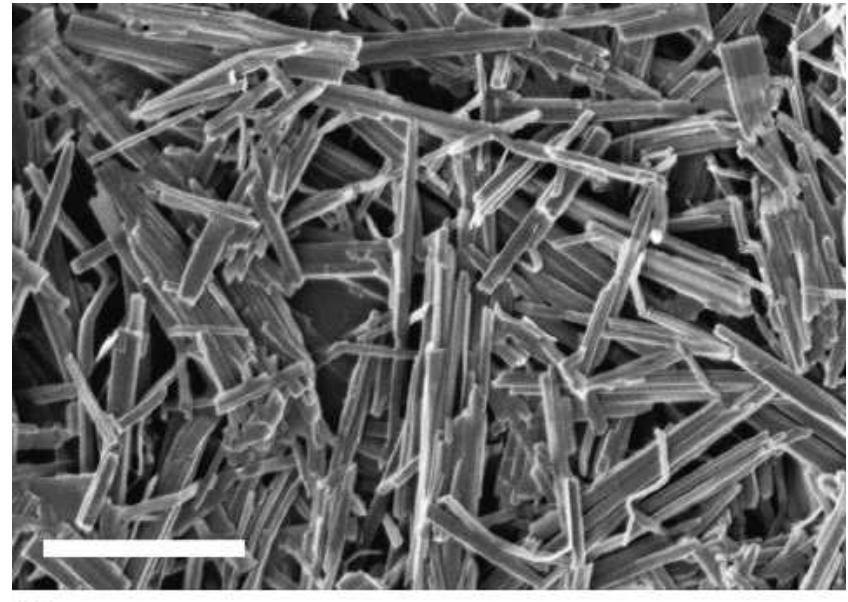

(a)

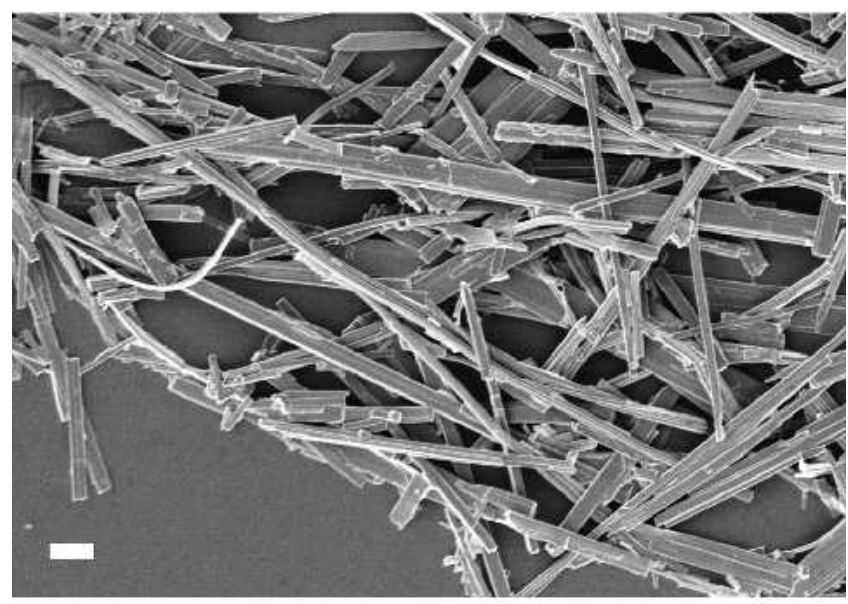

(b)

FIG. 8. SEM images (scale bar $=1 \mu \mathrm{m}$ ) of fibrous magnesium vanadates grown in the hydrothermal $\mathrm{Mg}(\mathrm{OH})_{2} / \mathrm{V}_{2} \mathrm{O}_{5}$ system starting from initial Mg:V-ratios of (a) 0.18 and (b) 0.38 .

as the interference with the peaks of a still unidentified impurity, did not allow for a deeper insight into the fine issues of the oxygen and hydrogen occupancies in the structure, which could have removed the formal inconsistency in the charge balance.

$\mathrm{Mg}_{7-\mathrm{x}}\left(\mathrm{VO}_{4}\right)_{4}(\mathrm{OH})_{3}$ is the first quasi-binary vanadate exhibiting this structural motif, because the isostructural $\mathrm{Zn}_{7}(\mathrm{OH})_{3}\left(\mathrm{SO}_{4}\right)\left(\mathrm{VO}_{4}\right)_{3}$ contains both $\mathrm{SO}_{4}$ and $\mathrm{VO}_{4}$ tetrahedra. ${ }^{64}$ The latter compound has unexpectedly emerged as a side product from the hydrothermal treatment of $\mathrm{VO}(\mathrm{OH})_{2}$ and $\mathrm{NaOH}$ at $280{ }^{\circ} \mathrm{C}$ together with the main products, $\sigma-\mathrm{Zn}_{0.25} \mathrm{~V}_{2} \mathrm{O}_{5} \cdot \mathrm{H}_{2} \mathrm{O}$ and $\mathrm{VO}_{2}$. No morphological features have been reported for the zinc sulfate vanadate. ${ }^{64}$ The synthesis of $\mathrm{Mg}_{7-\mathrm{x}}\left(\mathrm{VO}_{4}\right)_{4}(\mathrm{OH})_{3}$, however, provides both a high yield ( $\sim 95 \%)$ and an interesting morphology.

Recently, V-Mg-O-based catalysts have attracted considerable interest ${ }^{66}$ and further investigations on $\mathrm{Mg}_{7-\mathrm{x}}\left(\mathrm{VO}_{4}\right)_{4}(\mathrm{OH})_{3}$ are under way. 


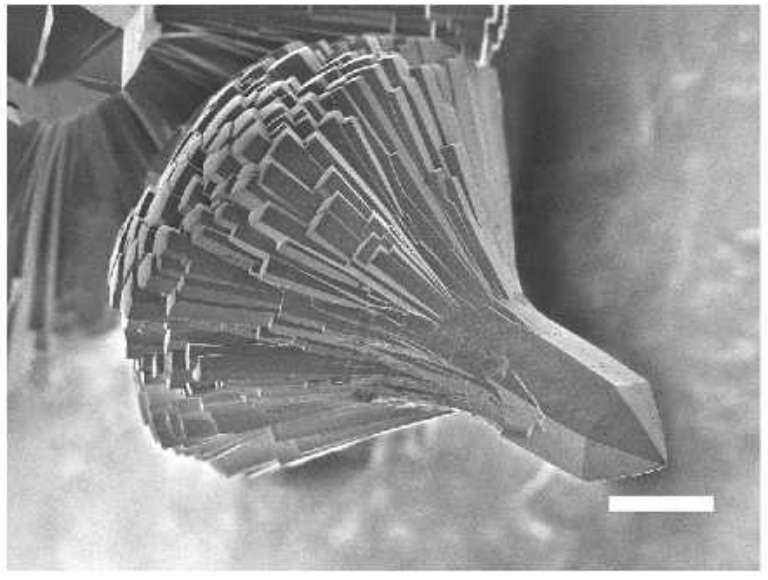

(a)

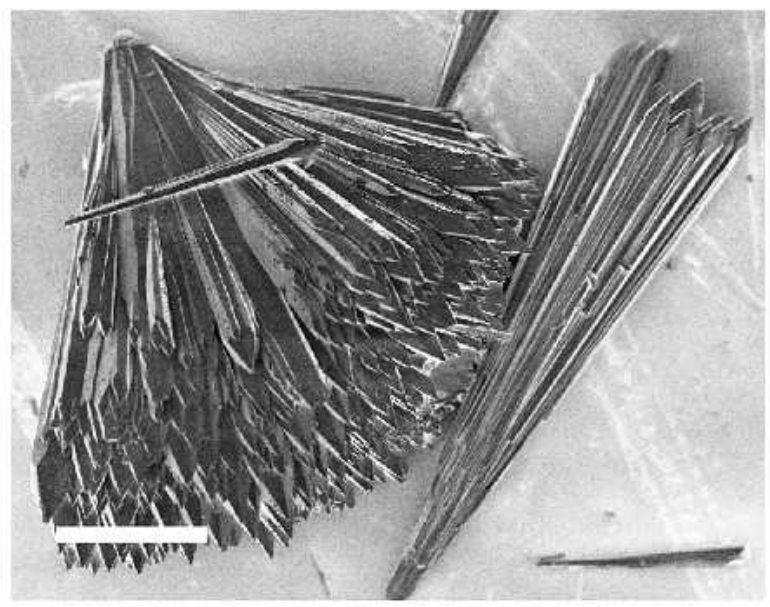

(b)

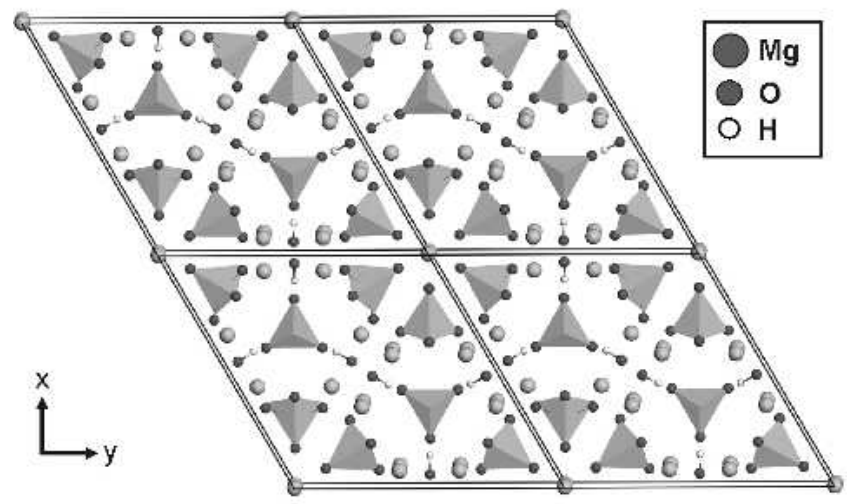

(c)

FIG. 9. SEM images (scale bar $=40 \mu \mathrm{m}$ ) of flower-like growth patterns of $\mathrm{Mg}_{7-\mathrm{x}}\left(\mathrm{VO}_{4}\right)_{4}(\mathrm{OH})_{3}$ emerging from the $\mathrm{Mg}(\mathrm{OH})_{2} / \mathrm{V}_{2} \mathrm{O}_{5}$ system (initial $\mathrm{Mg}: \mathrm{V}$-ratio of 1.5 ) after 6 days of hydrothermal treatment at $180{ }^{\circ} \mathrm{C}(\mathrm{a}, \mathrm{b})$ together with a view of the crystal structure of $\mathrm{Mg}_{7-\mathrm{x}}\left(\mathrm{VO}_{4}\right)_{4}(\mathrm{OH})_{3}$ (the $\mathrm{VO}_{4}$-tetrahedra are indicated in gray) along [001] (c).

\section{B. Formation of $\beta-\mathrm{SrV}_{2} \mathrm{O}_{6}$ in the $\mathrm{Sr}(\mathrm{OH})_{2} /$ $\mathrm{V}_{\mathbf{2}} \mathrm{O}_{\mathbf{5}}$ system}

At lower M:V-ratios (0.2-0.3), the hydrothermal $\mathrm{M}(\mathrm{OH})_{2} / \mathrm{V}_{2} \mathrm{O}_{5}(\mathrm{M}=\mathrm{Mg}$, Sr) systems both afford anisotropic vanadates. However, an increase of the Sr:Vratio triggers the formation of a yellow compound that can be mechanically separated from the accompanying small amounts of red, fibrous vanadate side products. The XRD pattern of the yellow compound [orthorhombic, $\mathrm{a}=12.550(1) \AA, \mathrm{b}=$ 9.672(1) $\AA$, $\mathrm{c}=3.683(1) \AA]$ could be assigned to $\beta-\mathrm{SrV}_{2} \mathrm{O}_{6}[$ Pnma, a $=9.666(1) \AA$, $\mathrm{b}=3.681(4) \AA, \mathrm{c}=12.529(3) \AA] .{ }^{67}$ The hydrothermally grown $\beta-\mathrm{SrV}_{2} \mathrm{O}_{6}$ consists of fibers with diameters between $300 \mathrm{~nm}$ and $2 \mu \mathrm{m}$ and lengths of $20 \mu \mathrm{m}$ and above (Fig. 10). The resulting aspect ratio of $\beta-\mathrm{SrV}_{2} \mathrm{O}_{6}$ is lower than that of the unidentified fibrous side product (diameters of 100-200 $\mathrm{nm}$ and lengths up to $30 \mu \mathrm{m}$ ). Its formation could neither be completely inhibited by an excess of $\mathrm{Sr}(\mathrm{OH})_{2}$ in the reaction mixture nor did prolonged hydrothermal treatments (37 days) afford phase pure $\beta-\mathrm{SrV}_{2} \mathrm{O}_{6}$. The high-temperature modification $\beta-\mathrm{SrV}_{2} \mathrm{O}_{6}$ consists of $\mathrm{V}_{2} \mathrm{O}_{6}$ double strings as a characteristic structural feature that occurs in $\mathrm{PbV}_{2} \mathrm{O}_{6}$ as well. ${ }^{68}$ Nevertheless, the hydrothermal synthesis of $\beta-\mathrm{SrV}_{2} \mathrm{O}_{6}$ at $180{ }^{\circ} \mathrm{C}$ is a quite unexpected result because the original solid state synthesis required several reaction steps at elevated temperatures. ${ }^{67}$ Therefore, the hydrothermal production of anisotropic $\beta-\mathrm{SrV}_{2} \mathrm{O}_{6}$ is a preparative shortcut that illustrates how the hydrothermal approach can be used for the convenient synthesis of metastable phases that are difficult to access with other preparative methods. As has been shown for the previously mentioned flower-shaped hexagonal magnesium vanadates, the formation of an anisotropic morphology is an additional benefit of the hydrothermal route.

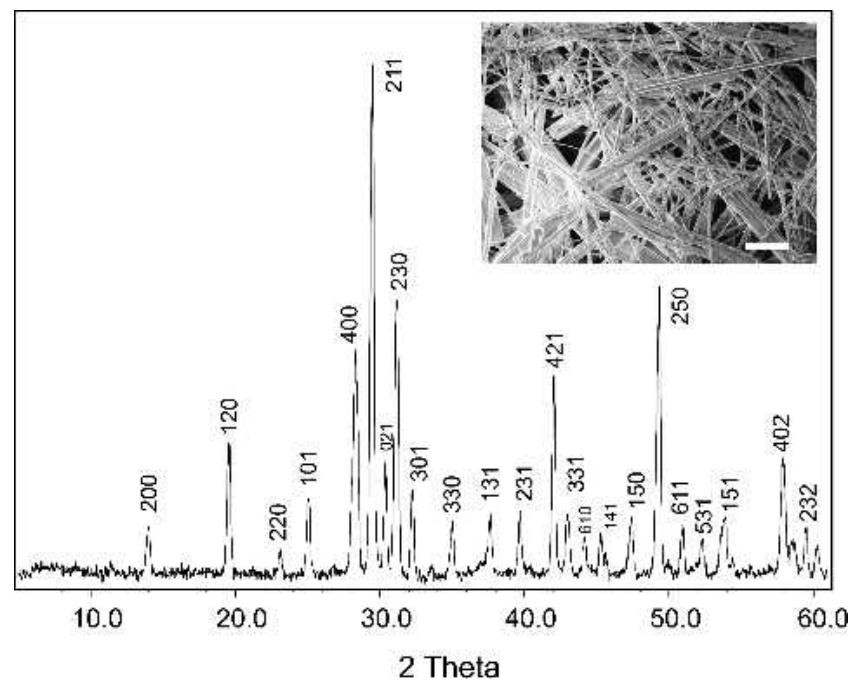

FIG. 10. XRD pattern of rod-shaped $\beta-\mathrm{SrV}_{2} \mathrm{O}_{6}$ obtained from the hydrothermal reaction of $\mathrm{Sr}(\mathrm{OH})_{2}$ and $\mathrm{V}_{2} \mathrm{O}_{5}$ together with a representative SEM image (inset; scale bar $=3 \mu \mathrm{m}$ ). 


\section{Formation of catena- $\mathrm{Ba}\left(\mathrm{VO}_{3}\right)_{2} \cdot \mathrm{H}_{2} \mathrm{O}$ in the $\mathrm{Ba}(\mathrm{OH})_{2} / \mathrm{V}_{2} \mathrm{O}_{5}$ system}

The system $\mathrm{Ba}(\mathrm{OH})_{2} / \mathrm{V}_{2} \mathrm{O}_{5}$ was screened in the $\mathrm{Ba}: \mathrm{V}$ range between 0.2 and 3 . The formation of fibrous products was observed for Ba: $\mathrm{V}$-ratios around 0.2 , which is in line with the hydrothermal behavior of the aforementioned systems $\mathrm{Mg}(\mathrm{OH})_{2^{-}}$and $\mathrm{Sr}(\mathrm{OH})_{2} / \mathrm{V}_{2} \mathrm{O}_{5}$, respectively. The XRD pattern of the barium vanadate fibers is closely related to the hewettite compound $\mathrm{Ba}_{0.97}\left(\mathrm{~V}_{6} \mathrm{O}_{16}\right)\left(\mathrm{H}_{2} \mathrm{O}\right)_{1.67} \cdot{ }^{41}$

In the $\mathrm{Ba}: \mathrm{V}$-window between 0.4 and 0.8 , $\mathrm{Ba}\left(\mathrm{VO}_{3}\right)_{2} \cdot 2 \mathrm{H}_{2} \mathrm{O}$ emerges as the main phase together with a small amount of side products indicated by a broad reflection in the XRD pattern around $10^{\circ} \theta$ (Fig. 11). The lattice parameters [orthorhombic, $\mathrm{a}=9.719$ (2) $\AA$, b = 8.996(2) $\AA, c=7.399(1) \AA]$ agree well with the literature data for $\mathrm{Ba}\left(\mathrm{VO}_{3}\right)_{2} \cdot 2 \mathrm{H}_{2} \mathrm{O}\left[P 2_{1}{ }_{1}{ }_{1}{ }_{1}, \mathrm{a}=8.997(2) \AA\right.$, $\mathrm{b}=9.728(2) \AA, \mathrm{c}=7.409(1) \AA] .{ }^{69}$ The optimum Ba:Vratio for fiber formation is around 0.4 , and the $\mathrm{Ba}\left(\mathrm{VO}_{3}\right)_{2} \cdot 2 \mathrm{H}_{2} \mathrm{O}$ rods exhibit diameters around 150 $200 \mathrm{~nm}$ and microscale lengths up to $5 \mu \mathrm{m}$. An excess of barium cations in the starting material reduces the yield of $\mathrm{Ba}\left(\mathrm{VO}_{3}\right)_{2} \cdot 2 \mathrm{H}_{2} \mathrm{O}$, and when a $\mathrm{Ba}: \mathrm{V}$-threshold value of 2 is exceeded, the formation of nanostructured $\mathrm{Ba}_{3}\left(\mathrm{VO}_{4}\right)_{2}$ with an irregular morphology sets in. $\mathrm{Ba}\left(\mathrm{VO}_{3}\right)_{2} \cdot 2 \mathrm{H}_{2} \mathrm{O}$ displays a unique structural motif among the large family of vanadates; it contains infinite, twisted spiral chains of $\mathrm{VO}_{4}$ tetrahedra extending along the c-axis. ${ }^{69}$ This may favor the formation of rod-shaped particles. The synthesis of single crystals of $\mathrm{Ba}\left(\mathrm{VO}_{3}\right)_{2} \cdot 2 \mathrm{H}_{2} \mathrm{O}$ required special precautions ${ }^{70}$ and the straightforward hydrothermal approach toward fibrous catena- $\mathrm{Ba}\left(\mathrm{VO}_{3}\right)_{2} \cdot 2 \mathrm{H}_{2} \mathrm{O}$ represents an interesting synthetic alternative.

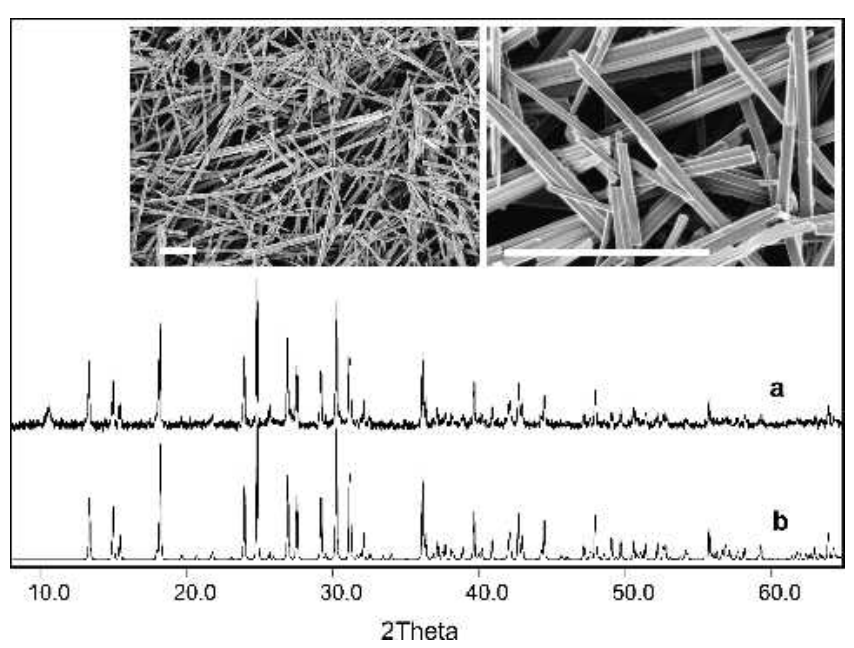

FIG. 11. XRD pattern and representative SEM images (inset; scale bar $=2 \mu \mathrm{m})$ of fibrous $\mathrm{Ba}\left(\mathrm{VO}_{3}\right)_{2} \cdot 2 \mathrm{H}_{2} \mathrm{O}$ obtained from the $\mathrm{Ba}(\mathrm{OH})_{2} / \mathrm{V}_{2} \mathrm{O}_{5}$ hydrothermal system (a) versus the literature XRD data for $\mathrm{Ba}\left(\mathrm{VO}_{3}\right)_{2} \cdot 2 \mathrm{H}_{2} \mathrm{O}(\mathrm{b})$.

\section{DISCUSSION}

The hydrothermal field studies on the formation of anisotropic alkali and alkaline earth vanadates reveal specific trends with respect to: (i) the synthetic efficiency of the hydrothermal process; (ii) the role of the anions and cations in comparison to other transition metal oxide-based hydrothermal systems, and (iii) the formation of fluorovanadates and composite materials.

Concerning the hydrothermal procedure, the development of one-step, phase pure syntheses may require considerable optimization effort in the first place. This is due to the high reactivity and redox activity of $\mathrm{V}_{2} \mathrm{O}_{5}{ }^{9}$ that gives rise to the formation of a multitude of phases so that their individual parameter windows are difficult to access. The extensive studies of Oka et al. on the hydrothermal preparation of alkali- and alkaline earth vanadates (cf. literature cited in Tables II and III) illustrate how carefully the reaction parameters must be adjusted to address a targeted product. This process becomes increasingly complex when not only the crystal structure but also the morphology of the resulting vanadate is to be controlled. Once this optimization process has been mastered, however, it is usually worth the preparative effort because the resulting hydrothermal protocols can then afford gram quantities of the fibers in a single run without pre-treatments or complicated workups. This renders them suitable for the technical production of larger quantities. Moreover, the development of one-step reactions is essential for further scale-up processes because the sensitivity of a hydrothermal system toward parameter shifts ${ }^{71}$ may increase drastically with each additional preparative step (cf. synthesis of bannermanite, Sec. III. D). As anisotropic lithium vanadates have recently attracted considerable research interest due to their versatile electrochemical properties, ${ }^{15}$ the newly synthesized fernandinite-related $\mathrm{Li}_{\mathrm{x}} \mathrm{V}_{2} \mathrm{O}_{5}$ fibers are currently investigated with respect to battery applications.

In the course of our previous work, we have experienced two different scenarios concerning the product morphologies emerging from the hydrothermal reaction of transition metal oxide-precursors in the presence of ionic additive substances.

Firstly, we have conducted extensive field studies on the interaction of molybdenum oxide precursors with alkali and alkaline earth halides. ${ }^{46}$ Contrary to the anisotropic vanadate formation discussed in this study, most of the analogous molybdenum oxide-based reactions either led to millimeter-sized molybdate crystals through the reaction with the ionic compound ${ }^{72}$ or to the production of additive-free $\mathrm{MoO}_{3}$ fibers. In other words, the concept of initiating the growth of anisotropic products in a given hydrothermal system through the presence of ionic auxiliary substances did not work for the investigated molybdate systems. Furthermore, many of the well-known 
organic morphology-directing additives (e.g., organic acids, carbohydrates, amine surfactants) underwent alternative intercalation and redox processes that led to layered or amorphous composite materials with no recognizable morphology.

In contrast to these observations, our according studies on the hydrothermal interaction of ammonium metatungstate $^{73}$ with alkali chlorides clearly revealed a morphologydirecting effect of the alkali cations. Whereas they are incorporated into the hexagonal channels of the tungstate framework, they also transform it into a variety of nanoscale morphologies. The kinetic and mechanistic details of this process are currently investigated in terms of in situ EXAFS and EDXRD analyses. ${ }^{74,75}$

Thus, the hydrothermal reaction of $\mathrm{V}_{2} \mathrm{O}_{5}$ with alkali/ alkaline earth halides represents a complex intermediate situation: the versatile structural chemistry of vanadates gives rise to a multitude of structural motifs, and the observed fibrous morphologies can be further addressed through adjusting the additive concentration and through the choice of the counteranion (cf. Secs. III. C and III. D). However, the origin of anisotropy-may it be an inherent feature of the crystal structure or a result of surface capping during the growth process-must be investigated individually for each vanadate system. Given that many of their crystal structures still remain unknown and that very little information is available on the mechanisms of hydrothermal vanadate growth, this remains a major challenge that is in the focus of our current in situ investigations.

As a detailed exploration of these complicated morphology-synthesis relationships is beyond the scope of the present study, the results are summarized in an empirical fashion from the preparative point of view: as has been observed for the hydrothermal reactivity of alkali halide/Mo(VI)-based systems as well, ${ }^{46}$ both the cation and the anion exert a significant influence on the phase and on the morphology of the fibrous alkali vanadates. The impact of the cations can be systemized in terms of a synthetic field (Fig. 1 and Table VI), and a fine-tuned access to selected products is then possible by choosing the appropriate anion. Among the investigated alkali vanadate systems, the cations can be classified as follows with respect to their general tendency toward rod formation: $\mathrm{Li}^{+} \approx \mathrm{Na}^{+}>\mathrm{K}^{+}>\mathrm{Rb}^{+} \approx \mathrm{Cs}^{+}$. The influence of the anions on the aspect ratio of the resulting vanadates decreases in the following order: $\mathrm{F}^{-} \approx \mathrm{HO}^{-}>$ $\mathrm{Cl}^{-} \approx \mathrm{Br}^{-}>\mathrm{I}^{-}$. Consequently, the "hard-hard" $\mathrm{MX}$ combinations ("mineralizers" such as $\mathrm{LiF}$ or $\mathrm{NaF}$ ) are most suitable for fiber formation, whereas the "soft-soft" compounds (e.g., $\mathrm{RbBr}$ or $\mathrm{CsI}$ ) do not favor the growth of anisotropic products. This is just a formal "rule of thumb" for synthetic purposes. By no means does it reflect the complex interplay of the hydrothermal parameters $(\mathrm{pH}, \mathrm{T}, \mathrm{c}, \mathrm{t} \ldots)$ with the structural chemistry arising from the incorporation of the cation and the additional anionsurface interactions. ${ }^{71}$

Among all systems investigated, the fibrous materials are always formed within a specific $(\mathrm{M}: \mathrm{V})$-parameter window, and the majority of them exhibits layered structural motifs that are closely related to natural vanadium minerals. ${ }^{51,58}$ Beyond the parameter window for fiber formation, however, other (fluoro-)vanadate types with interesting microscale morphologies can be accessed (cf. Sec. IV on alkaline earth-based systems). Sometimes, their hydrothermal preparation represents a cost-saving and time-saving alternative to lengthy solid state syntheses (cf. formation of $\beta-\mathrm{SrV}_{2} \mathrm{O}_{6}$ fibers, Sec. IV. B) and provides morphology control options as a further advantage. This outlines the preparative flexibility of the hydrothermal method: both nanostructured materials and single-crystalline compounds with novel structural features can be accessed from a common hydrothermal protocol. ${ }^{46}$

\section{CONCLUSIONS}

An extensive hydrothermal field study of the $\mathrm{MX}_{\mathrm{n}} /$ $\mathrm{V}_{2} \mathrm{O}_{5}(\mathrm{n}=1,2 ; \mathrm{M}=$ alkali/alkaline earth cation; $\mathrm{X}=$ $\mathrm{OH}, \mathrm{F}-\mathrm{I})$ systems revealed that they bring forward a multitude of anisotropic vanadates.

(1) Among the alkali vanadates, lithium- and sodium vanadate fibers (fernandinite-related $\mathrm{Li}_{\mathrm{x}} \mathrm{V}_{2} \mathrm{O}_{5} \cdot \mathrm{nH}_{2} \mathrm{O}$ and bannermanite/barnesite-related phases, respectively) demonstrate that the resulting morphology is a sensitive function of the reaction parameters, namely of the initial $(\mathrm{M}: \mathrm{V})$-ratio in the starting material and of the choice of the anion.

(2) Many of the products formed in the remaining potassium-, rubidium, and cesium vanadate systems exhibit yet unknown structural motifs, thereby demonstrating the complex interaction of the alkali-based additives with the $\mathrm{V}_{2} \mathrm{O}_{5}$ precursor.

(3) Similar trends apply for the alkaline earth hydroxide/ $\mathrm{V}_{2} \mathrm{O}_{5}$ hydrothermal systems: whereas the fibrous products formed from (M:V)-ratios below 0.4 exhibit a complex structural chemistry, higher (M:V)-ratios open up a convenient hydrothermal approach to anisotropic alkaline earth vanadates with defined structural motifs and a distinct anisotropic morphology, such as fibrous $\beta-\mathrm{SrV}_{2} \mathrm{O}_{6}$ and $\mathrm{Ba}\left(\mathrm{VO}_{3}\right)_{2} \cdot 2 \mathrm{H}_{2} \mathrm{O}$.

(4) Finally, the rich structural chemistry of the alkali vanadates and the parameter sensitivity of the vanadate equilibria in solution renders the hydrothermal preparation of anisotropic vanadates far more complicated than the straightforward procedures that we have set up for comparable molybdenum- and tungsten-based systems. ${ }^{46,74}$ Furthermore, the process of hydrothermal vanadate formation in the given systems appears to require minimum reaction times around 1 day, whereas the 
formation of $\mathrm{MoO}_{3}$ rods proceeds on a minute scale. ${ }^{3}$ Our preliminary experiments have indicated that the difference in kinetics and reactivity between the Mo-, W-, and V-oxide based hydrothermal systems could be used for coating reactions leading to the formation of combined nanomaterials, e.g., $(\mathrm{V}, \mathrm{W}) \mathrm{O}_{\mathrm{x}}$-fibers. ${ }^{47}$ Therefore, the present hydrothermal trends for vanadate synthesis are currently explored with respect to the production of ternary oxidic nanomaterials.

All in all, the present study provides some synthetic guidelines for the hydrothermal preparation of anisotropic vanadates that serve as a starting point for detailed preparative and mechanistic studies, especially in the preparation of novel nanostructured cathode materials and catalysts.

\section{ACKNOWLEDGMENTS}

We thank Prof. Dr. R. Nesper (Laboratory of Inorganic Chemistry, ETH Zurich) for his steady interest and for the continuous support of this work. This work was supported by the ETH Zurich, by the Swiss National Science Foundation (MaNEP-Materials with Novel Electronic Properties), and by the National Research Program "Supramolecular Functional Materials".

\section{REFERENCES}

1. The Chemistry of Nanostructured Materials, edited by P. Yang (World Scientific Publishers, Singapore, 2003).

2. G.R. Patzke, F. Krumeich, and R. Nesper: Oxidic nanotubes and nanorods-anisotropic materials for a future nanotechnology. Angew. Chem. Int. Ed. Engl. 41, 2446 (2002).

3. A. Michailovski, J-D. Grunwaldt, A. Baiker, R. Kiebach, W. Bensch, and G.R. Patzke: Studying the solvothermal formation of $\mathrm{MoO}_{3}$ fibers by complementary in situ EXAFS/EDXRD techniques. Angew. Chem. Int. Ed. Engl. 44, 5643 (2005).

4. M. Niederberger, F. Krumeich, H-J. Muhr, M. Müller, and R. Nesper: Synthesis and characterization of novel nanoscopic molybdenum oxide fibers. J. Mater. Chem. 11, 1941 (2001).

5. T. Chirayil, P.Y. Zavalij, and M.S. Whittingham: Hydrothermal synthesis of vanadium oxides. Chem. Mater. 10, 2629 (1998).

6. J. Livage: Vanadium pentoxide gels. Chem. Mater. 3, 578 (1991).

7. Y. Wang and G. Cao: Synthesis and enhanced intercalation properties of nanostructured vanadium oxides. Chem. Mater. 18, 2787 (2006).

8. M.S. Whittingham, Y. Song, S. Lutta, P.Y. Zavalij, and N.A. Chernova: Some transition metal (oxy)phosphates and vanadium oxides for lithium batteries. J. Mater. Chem. 15, 3362 (2005).

9. P.Y. Zavalij and M.S. Whittingham: Structural chemistry of vanadium oxides with open frameworks. Acta Crystallogr. B55, 627 (1999).

10. P.J. Hagrman, R.C. Finn, and J. Zubieta: Molecular manipulation of solid state structure: Influences of organic components on vanadium oxide architectures. Solid State Sci. 3, 745 (2001).

11. C.R.A. Catlow, D.H. Gay, A.L. Rohl, and D.C. Sayle: Simulating the structures of crystals and their surfaces. Top. Catal. 3, 135 (1996).
12. C.N.R. Rao and B. Raveau: Transition Metal Oxides (VCH Publishers, New York, 1995).

13. P. Boulet, A. Baiker, H. Chermette, F. Gilardoni, J.C. Volta, and J. Weber: Oxidation of methanol to formaldehyde catalyzed by $\mathrm{V}_{2} \mathrm{O}_{5}$. A density functional study. J. Phys. Chem. B 37, 9659 (2002).

14. J. Spengler, F. Anderle, E. Bosch, R.K. Grasselli, B. Pillep, P. Behrens, O.B. Lapina, A.A. Shubin, H.J. Eberle, and H. Knozinger: Antimony oxide-modified vanadia-based catalysts-Physical characterization and catalytic properties. J. Phys. Chem. B 105, 10772 (2001).

15. M.E. Spahr, P. Stoschitzki-Bitterli, R. Nesper, O. Haas, and P. Novak: Vanadium oxide nanotubes-A new nanostructured redox-active material for the electrochemical insertion of lithium. J. Electrochem. Soc. 146, 2780 (1999).

16. W.J. Stark, K. Wegner, S.E. Pratsinis, and A. Baiker: Flame aerosol synthesis of vanadia-titania nanoparticles: Structural and catalytic properties in the selective catalytic reduction of $\mathrm{NO}$ by $\mathrm{NH}_{3}$. J. Catal. 197, 182 (2001).

17. C. Feldmann: Polyol-mediated synthesis of nanoscale functional materials. Adv. Funct. Mater. 13, 101 (2003).

18. F. Krumeich, H-J. Muhr, M. Niederberger, F. Bieri, B. Schnyder, and R. Nesper: Morphology and topochemical reactions of novel vanadium oxide nanotubes. J. Am. Chem. Soc. 121, 8324 (1999).

19. X. Liu, C. Taschner, A. Leonhardt, M.H. Rummeli, T. Pichler, T. Gemming, B. Buchner, and M. Knupfer: Structural, optical, and electronic properties of vanadium oxide nanotubes. Phys. Rev. B 72, 115407 (2005).

20. Z. Gui, R. Fan, W. Mo, X. Chen, L. Yang, S. Zhang, Y. Hu, Z. Wang, and W. Fan: Precursor morphology controlled formation of rutile $\mathrm{VO}_{2}$ nanorods and their self-assembled structure. Chem. Mater. 14, 5053 (2002).

21. T. Watanabe, W-S. Cho, W.L. Suchanek, M. Endo, Y. Ikuma, and M. Yoshimura: Direct fabrication of crystalline vanadates films by hydrothermal-electrochemical method. Solid State Sci. 3, 183 (2001).

22. T.A. Chirayil, P.Y. Zavalij, and M.S. Whittingham: A new vanadium dioxide cathode. J. Electrochem. Soc. 143, L193 (1996).

23. T. Chirayil, P.Y. Zavalij, and M.S. Whittingham: Hydrothermal synthesis and characterization of " $\mathrm{Li}_{\mathrm{x}} \mathrm{V}_{2-\delta} \mathrm{O}_{4-\delta} \mathrm{H}_{2} \mathrm{O}$ ". Solid State Ionics 84, 163 (1996).

24. H.Y. Xu, H. Wang, Z.Q. Song, Y.W. Wang, H. Yan, and M. Yoshimura: Novel chemical method for synthesis of $\mathrm{LiV}_{3} \mathrm{O}_{8}$ nanorods as cathode material for lithium ion batteries. Electrochim. Acta 49, 349 (2004).

25. K. Ozawa, L. Wang, H. Fujii, M. Eguchi, M. Hase, and H. Yamaguchi: Preparation and electrochemical properties of the layered material of $\mathrm{Li}_{\mathrm{x}} \mathrm{V}_{\mathrm{y}} \mathrm{O}_{2}(\mathrm{x}=0.86$ and $\mathrm{y}=0.8)$. J. Electrochem. Soc. 153 (1), A 117 (2006).

26. T. Oka, Y. Oka, and N. Yamamoto: Layered structures of hydrated vanadium oxides-Part 1. J. Mater. Chem. 2(3), 331 (1992).

27. X. Wu, Y. Tao, L. Dong, and J. Hong: Synthesis and characterization of self-assembling $\left(\mathrm{NH}_{4}\right)_{0.5} \mathrm{~V}_{2} \mathrm{O}_{5}$. J. Mater. Chem. 14, 901 (2004).

28. Y. Oka, T. Yao, and N. Yamamoto: Hydrothermal synthesis and structure refinements of alkali-metal trivanadates $\mathrm{AV}_{3} \mathrm{O}_{8}(\mathrm{~A}=\mathrm{K}$, Rb, Cs). Mater. Res. Bull. 32, 1201 (1997).

29. Y. Oka, T. Yao, N. Yamamoto, and O. Tamada: Hydrothermal synthesis of vanadium oxide bronzes $\mathrm{M}_{\mathrm{x}} \mathrm{V}_{3} \mathrm{O}_{8}(\mathrm{VO})_{\mathrm{y}} \cdot \mathrm{nH}_{2} \mathrm{O}(\mathrm{M}=\mathrm{K}$, Rb, Ba). Mater. Res. Bull. 32, 59 (1997).

30. Y. Oka, T. Yao, and N. Yamamoto: Layered structures of hydrated vanadium oxides-Part 4. J. Mater. Chem. 5(9), 1423 (1995). 
31. H. Xu, W. He, H. Wang, and H. Yan: Solvothermal synthesis of $\mathrm{K}_{2} \mathrm{~V}_{3} \mathrm{O}_{8}$ nanorods. J. Cryst. Growth 260, 447 (2004).

32. F-N. Shi, J. Rocha, A.B. Lopes, and T. Trinidade: Morphological micro-patterning of tubular-windows on crystalline $\mathrm{K}_{2} \mathrm{~V}_{3} \mathrm{O}_{8}$ sheets. J. Cryst. Growth 273, 572 (2005).

33. T. Yao, Y. Oka, and N. Yamamoto: Layered structures of hydrated vanadium oxides-Part 5. J. Mater. Chem. 6(7), 1195 (1996).

34. Y. Oka, F. Saito, T. Yao, and N. Yamamoto: Crystal structure of $\mathrm{Cs}_{2} \mathrm{~V}_{4} \mathrm{O}_{11}$ with unusual V-O coordinations. J. Solid State Chem. 134, 52 (1997).

35. M. Ushio: Hydrothermal synthesis of fibrous calcium vanadate crystal in the system $\mathrm{CaO}-\mathrm{V}_{2} \mathrm{O}_{5}-\mathrm{H}_{2} \mathrm{O}$. Nippon Kagaku Kaishi 2, 185 (1979).

36. Y. Oka, T. Yao, and N. Yamamoto: Crystal structures of hydrated vanadium oxides with $\delta$-type $\mathrm{V}_{2} \mathrm{O}_{5}$ layers: $\delta-\mathrm{M}_{0.25} \mathrm{~V}_{2} \mathrm{O}_{5} \cdot \mathrm{H}_{2} \mathrm{O}$; M = Ca, Ni. J. Solid State Chem. 132, 323 (1997).

37. Y. Oka, T. Yao, N. Yamamoto, M. Ueda, and S. Maegawa: Synthesis and crystal structure of $\mathrm{SrV}_{4} \mathrm{O}_{9}$ in a metastable state. J. Solid State Chem. 149, 414 (2000).

38. T. Yao, Y. Oka, and N. Yamamoto: Structure refinement of barium metavanadate $\mathrm{BaV}_{2} \mathrm{O}_{6}$. Inorg. Chim. Acta 238, 165 (1995).

39. Y. Oka, T. Yao, and N. Yamamoto: Hydrothermal synthesis and crystal structure of $\mathrm{BaV}_{3} \mathrm{O}_{8}$. J. Solid State Chem. 137, 407 (1995).

40. Y. Oka, O. Tamada, T. Yao, and N. Yamamoto: Hydrothermal synthesis and crystal structure of a novel barium vanadium oxide: $\mathrm{Ba}_{0.4} \mathrm{~V}_{3} \mathrm{O}_{8}(\mathrm{VO})_{0.4} \cdot \mathrm{nH}_{2} \mathrm{O}$. J. Solid State Chem. 114, 359 (1995).

41. Y. Oka, T. Yao, S. Sato, and N. Yamamoto: Hydrothermal synthesis and crystal structure of barium hewettite: $\mathrm{BaV}_{6} \mathrm{O}_{16} \cdot \mathrm{nH}_{2} \mathrm{O}$. J. Solid State Chem. 140, 219 (1998).

42. X. Wang, L. Liu, R. Bontchev, and A.J. Jacobson: Electrochemicalhydrothermal synthesis and structure determination of a novel layered mixed-valence oxide: $\mathrm{BaV}_{7} \mathrm{O}_{16} \cdot \mathrm{nH}_{2} \mathrm{O}$. Chem. Commun. 1009 (1998).

43. Y. Oka, T. Yao, and N. Yamamoto: Hydrothermal synthesis and crystal structure of a new barium vanadium bronze $\mathrm{Ba}_{1+\mathrm{x}} \mathrm{V}_{8} \mathrm{O}_{21}$ with a tunnel structure. J. Solid State Chem. 150, 330 (2000).

44. Y. Kanke, Y. Oka, and T. Yao: Hydrothermal synthesis and crystal structure of $\mathrm{Ba}_{6}\left[\mathrm{~V}_{10} \mathrm{O}_{30}\left(\mathrm{H}_{2} \mathrm{O}\right)\right] \cdot 2.5 \mathrm{H}_{2} \mathrm{O}$ with an unusual arrangement of $\mathrm{V}^{\mathrm{IV}}-\mathrm{O}$ polyhedra. J. Solid State Chem. 151, 130 (2000).

45. H. Zhang, D. Yang, D. Li, X. Ma, S. Li, and D. Que: Controllable growth of $\mathrm{ZnO}$ microcrystals by a capping-molecule-assisted hydrothermal process. Cryst. Growth Design 5, 547 (2005).

46. A. Michailovski, F. Krumeich, and G.R. Patzke: Solvothermal morphology studies: Alkali and alkaline earth molybdates. Helv. Chim. Acta 87, 1029 (2004).

47. A. Michailovski and G. R. Patzke: (in preparation).

48. P. Behrens, A. Glaue, C. Haggenmuller, and G. Schechner: Structure-directed materials syntheses: Synthesis field diagrams for the preparation of mesostructured silicas. Solid State Ionics 101, 255 (1997).

49. G. Pausewang and K. Dehnicke: Alkaline oxofluoro metalates of transition metals II. Structure of some oxide fluorides with pentavalent vanadium. Z. Anorg. Allg. Chem. 369, 265 (1969).

50. R. Mattes and H. Foerster: The crystal structure of green $\mathrm{Cs}_{2}\left[\mathrm{VOF}_{4}\left(\mathrm{H}_{2} \mathrm{O}\right)\right]$ and its relationship to blue $\mathrm{Cs}_{2}\left[\mathrm{VOF}_{4}\left(\mathrm{H}_{2} \mathrm{O}\right)\right]$. J. Solid State Chem. 45, 154 (1982).

51. H.T. Evans, J.E. Post, D.R. Ross, and J.A. Nelen: The crystal structure and crystal chemistry of fernandinite and corvusite. Can. Mineral. 32, 339 (1994).

52. H.T. Evans and J.M. Hughes: Crystal chemistry of the natural vanadium bronzes. Am. Mineral. 75, 508 (1990).
53. A.R. West and F.P. Glasser: Preparation and crystal chemistry of some tetrahedral $\mathrm{Li}_{3} \mathrm{PO}_{4}$-type compounds. J. Solid State Chem. 4 , 20 (1972).

54. A.D. Weeks, D.R. Ross, and R.F. Marvin: Occurrence and properties of barnesite- $\mathrm{Na}_{2} \mathrm{~V}_{6} \mathrm{O}_{16} \cdot 3 \mathrm{H}_{2} \mathrm{O}$. A new hydrated sodium vanadate mineral from Utah. Am. Mineral. 48, 1187 (1963).

55. H.T. Evans: The crystal structure of hewettite. Can. Mineral. 27, 181 (1989)

56. A.D. Wadsley: Crystal chemistry of non-stoichiometric pentavalent vanadium oxides - crystal structure of $\mathrm{Li}_{1+\mathrm{x}} \mathrm{V}_{3} \mathrm{O}_{8}$. Acta Crystallogr. 10, 261 (1957).

57. S. Joanneau, A. Verbaere, S. Lascaud, and D. Guyomard: Improvement of the lithium insertion properties of $\mathrm{Li}_{1.1} \mathrm{~V}_{3} \mathrm{O}_{8}$. Solid State Ionics 177, 311 (2006).

58. H.G. Bachmann and W.H. Barnes: The crystal structure of a sodium-calcium variety of metahewettite. Can. Mineral. 7, 219 (1962).

59. G-T. Zhou, X. Wang, and J.C. Yu: Selected-control synthesis of $\mathrm{NaV}_{6} \mathrm{O}_{15}$ and $\mathrm{Na}_{2} \mathrm{~V}_{6} \mathrm{O}_{16} \cdot 3 \mathrm{H}_{2} \mathrm{O}$ single-crystalline nanowires. Cryst. Growth Design 5, 969 (2005).

60. C.W. Pistorius: Polymorphism and stability of some sodium cryolites to high pressures. J. Solid State Chem. 13, 208 (1975).

61. J.M. Hughes and L.W. Finger: Bannermanite, a new sodiumpotassium vanadate isostructural with $\beta-\mathrm{Na}_{\mathrm{x}} \mathrm{V}_{6} \mathrm{O}_{15}$. Am. Mineral. 68, 634 (1983).

62. A.D. Wadsley: The crystal structure of $\mathrm{Na}_{2-\mathrm{x}} \mathrm{V}_{6} \mathrm{O}_{15}$. Acta Crystallogr. 8, 695 (1955).

63. J. Livage: Synthesis of polyoxovanadates via "chimie douce". Coord. Chem. Rev. 178, 999 (1998).

64. K. Kato, Y. Kanke, Y. Oka, and T. Yao: Crystal structure of zinc hydroxide sulfate vanadate $(\mathrm{V}), \mathrm{Zn}_{7}(\mathrm{OH})_{3}\left(\mathrm{SO}_{4}\right)\left(\mathrm{VO}_{4}\right)_{3}$. Z. Krist. 213, 26 (1998).

65. J. Rodríguez-Carvajal: Recent advantages in magnetic structure determination by neutron powder diffraction. Physica B (Amsterdam) 192, 55 (1993).

66. G. Isaguliants and I.P. Belomestnykh: Selective oxidation of methanol to formaldehyde over V-Mg-O catalysts. Catal. Today 100, 441 (2005).

67. B. Schnuriger, R. Enjalbert, J.M. Savariault, and J. Galy: Synthesis and crystal structure of $\beta-\mathrm{SrV}_{2} \mathrm{O}_{6}$. J. Solid State Chem. 95, 397 (1991).

68. B.D. Jordan and C. Calvo: Crystal structure of lead metavanadate, $\mathrm{PbV}_{2} \mathrm{O}_{6}$. Can. J. Chem. 52, 2701 (1974).

69. L. Ulická, F. Pavelčik, and K. Huml: Structure of barium metavanadate monohydrate. Acta Crystallogr. C 43, 2266 (1987).

70. L. Zurková, J. Čorba, and V. Suchá: Preparation of crystalline $\mathrm{Ba}\left(\mathrm{VO}_{3}\right)_{2} \cdot \mathrm{H}_{2} \mathrm{O}$ and some of its physico-chemical properties. Chem. Zvesti. 22, 73 (1968).

71. J-P. Jolivet, M. Henry, and J. Livage: Metal Oxide Chemistry and Synthesis: From Solution to Solid State (John Wiley \& Sons, Chichester, UK, 2000).

72. A. Michailovski, J.B. Willems, N. Stock, and G.R. Patzke: Solvothermal synthesis and crystal structures of alkali molybdates. Helv. Chim. Acta 88, 2479 (2005).

73. A. Michailovski, F. Krumeich, and G.R. Patzke: Solvothermal synthesis of hierarchically structured pyrochlore ammonium tungstate nanospheres. Mater. Res. Bull. 39, 887 (2004).

74. A. Michailovski, R. Kiebach, W. Bensch, J-D. Grunwaldt, A. Baiker, S. Komarneni, and G.R. Patzke: Morphological and kinetic studies on hexagonal tungstates. Chem. Mater. (submitted).

75. A. Michailovski, F. Krumeich, and G.R. Patzke: Hierarchical growth of mixed ammonium molybdenum/tungsten bronze nanorods. Chem. Mater. 16, 1433 (2004). 